\title{
RADIOCARBON DATING HISTORY: EARLY DAYS, QUESTIONS, AND PROBLEMS MET
}

\author{
Ingrid U Olsson \\ Department of Physics and Materials Science, University of Uppsala, Sweden. Email: Ingrid.Olsson@ fysik.uu.se.
}

\begin{abstract}
W F Libby's new dating method from the 1940s, based on experience in physics and chemistry, opened possibilities to check and revise chronologies built on other principles than radioactive decay. Libby's method initially implied collaboration with archaeologists to demonstrate that it worked but also with physicists to improve the technique to measure low $\beta^{-}$activities. Chemists, geophysicists, botanists, physiologists, statisticians, and other researchers have contributed to a prosperous interdisciplinary development. Some pitfalls were not recognized from the beginning, although issues such as contamination problems were foreseen by Libby. Pretreatment of samples was discussed very early by de Vries and collaborators, among others. This subject has not yet been abandoned. Closely related to pretreatment is the choice of fraction to be dated and chemicals to be used, especially for accelerator mass spectrometry (AMS) measurements. Calibration against tree rings and comparison with dates obtained using other methods as well as intercomparison projects are partly history but still very actual. The impact by man and climate is also studied since the early days of the method. Also, the carbon cycle has been of great interest. The tools for measurements and statistical analysis have been improved during these first 3 or 4 decades, allowing interpretations not possible earlier. $\delta^{13} \mathrm{C}$ determinations are mostly very important and useful, but sometimes they have been misleading in discussions of the origin of carbon, especially for human tissues - the metabolism was not yet fully understood. The history and development of the method can only be illustrated by selected examples in a survey like this.
\end{abstract}

\section{INTRODUCTION}

In 1960, Libby was awarded the Nobel Prize in Chemistry for devising the radiocarbon dating method about $15 \mathrm{yr}$ earlier. He described the method as well as the technique used by him and collaborators in Chicago and even included a list of almost 1000 dates (Libby 1955). From the early literature, it is clear that the present activity of a sample must be measured, the initial activity and the half-life must be known, and that the sample had been a closed system since deposition until measurement in the laboratory. Initially, the method could be regarded as an absolute dating method. Enormous work has been done around the world to develop all the techniques involved in producing reliable dates. This effort includes calibration against an absolute chronology as dendrochronology and comparisons with tentative floating dendrochronologies and other chronologies.

Libby expressed his thanks to the archaeologists who, although first hesitated to supply specimens of otherwise dated material, collaborated with Libby by allowing him to test the new method on such material and prove that his method worked as well as could be expected at that time. Developments could then start.

Today, the statistical uncertainty of a date can be given in many laboratories as $30 \mathrm{or} 40 \mathrm{yr}$, or even as low as a tenth of that, whereas it is seen that the first dates (Libby 1955) were ascribed uncertainties about 200-300 yr. Initially, the samples were converted to black carbon deposited on the inner walls of a screen-wall Geiger counter. Two serious drawbacks must be mentioned: 1) since the efficiency had to be the same from measurement to measurement, the carbon layer had to be thick enough to allow the $\beta^{-}$particles from the carbon nearest to the wall to be absorbed; and 2) the preparation proved to be difficult since the black carbon easily absorbed contaminants deriving from nuclear tests. In spite of the originally appreciable uncertainty, the new dating method was immediately welcomed, especially by archaeologists, and little attention was paid to the problems with the method.

C 2009 by the Arizona Board of Regents on behalf of the University of Arizona Celebrating 50 Years of Radiocarbon 
For a long time, the laboratories and submitters of samples have, however, been aware of the risks of contamination in nature, during storing, treatment, and handling of samples (Libby 1955). In Uppsala, Libby even coined the expression "radiocarbon laundry" (Libby 1970). From recent papers in Radiocarbon, it is obvious that scientists in AMS laboratories, working with small samples, stress the importance of avoiding contamination with chemicals.

\section{LITERATURE REFLECTING THE VERY EARLY HISTORY OF RADIOCARBON DATING}

Many improvements and dates were presented already before the journal Radiocarbon was launched. The first 2 volumes were known as the American Journal of Science Radiocarbon Supplement. Initially, lists of dates, or measurements, with short descriptions of the context and laboratory procedures, were dominating.

The editors (RF Flint and ES Deevey Jr) of the first volume of Radiocarbon wrote in the preface that they wanted to improve the standards of presentation from that in Science and other journals. They wrote that the dates or lists were almost worthless as presented earlier. Still, I found even the new standardized lists of limited interest except from giving an idea about what research was going on and what procedures and equipment were used in the various laboratories. A punch-card system was also launched but very seldom used-at least by researchers in Uppsala. However, it was of considerable value to have results of datings printed by those responsible to avoid many results being quoted in error, even if the authors of lists may themselves introduce some.

Several bibliographies regarding ${ }^{14} \mathrm{C}$ measurements have been published, e.g. 2 general entries by the pioneer Hilde Levi in Copenhagen (1955, 1957); 2 extensive ones (arranged according to themes and consequently with some articles appearing more than once) by Johnson (1959) and Polach (1988), the latter covering the period 1947-68. Since then, too many titles are available to tempt anybody to assemble new extensive bibliographies.

There are no proceedings from the first ${ }^{14} \mathrm{C}$ conferences held in Copenhagen, Cambridge (2nd and 5th), Andover, and Groningen. Short reports are, however, published; see e.g. Polach (1988) and Radiocarbon 37(2):831. Some informative papers were exchanged. The number of participants was initially limited, although not strictly starting with that in Groningen in 1959. Proceedings from the 6th conference, held in Pullman in 1965, appeared, on request, in a mimeographed edition in 1966. The next "conference" was never announced as a ${ }^{14} \mathrm{C}$ conference. It was held in 1969 in Uppsala as Nobel Symposium 12 with a limited number of participants as decided by the Nobel Symposium Committee. Preliminary versions of the papers for that symposium were submitted and distributed before the symposium to allow the participants to adjust their own contributions and prepare themselves for the discussions. Three years later, a conference, announced as the 8th, was held in Lower Hutt, New Zealand. A preliminary version of the mimeographed proceedings was available already in 1972. The 9th international conference was held in 1976 in Los Angeles and La Jolla and published in 1979 by University of California Press. Since 1979, the conferences have been held every $3 \mathrm{yr}$ and proceedings have been published about $1 \mathrm{yr}$ thereafter by Radiocarbon.

\section{THE HALF-LIFE REVISION}

Libby listed all the determinations of the half-life he found, selected the 3 results he regarded as most reliable $(5580 \pm 45,5589 \pm 75,5513 \pm 165)$, and calculated a weighted average using the inverse square root of the errors quoted as the weight. He got $5568 \pm 30$, now called the Libby halflife. The value is often rounded to 5570. Three new determinations (Mann et al. 1961; Watt et al. 1961; Olsson et al. 1962) were discussed in 1962 at the conference in Cambridge and a mean was 
given as $5730 \pm 40$. The fact that several points given by Libby in his diagram (1955:10, Figure 1), many of them on Egyptian samples as checks against samples of known ages, were above the decay curve indicating a longer half-life than 5568, was a reason for us to start a new half-life determination. We then did not know about the other 2 ongoing determinations. Some of the problems are briefly related below.

Mass spectrometer determinations had to be performed. Slightly different values were obtained from the spectrometers involved. The mean value of 5730 is given after normalization to the value obtained in Aldermaston. Turnbull, who measured the Uppsala sample at AERE in Harwell together with Prosser, has a short discussion (private communication; Olsson and Karlén 1963) about the isotopic analysis. We reported our original value as $5680 \pm 40$ (rounded), using the Harwell mass spectrometer, where the indicated uncertainty denotes an estimated probable error (Olsson et al. 1962:254). Similarly, the value from the National Bureau of Standards (NBS) was given with a probable error. All 3 determinations are accompanied with a comment that the main difficulty in the measurement seemed to be the adsorption of gas on the walls of the handling system. Precautions were taken to avoid memory effects due to this fact. It seems as if earlier investigators overlooked this phenomenon.

The active $\mathrm{CO}_{2}$ had to be diluted with inactive gas to get suitable activities in the proportional counter. Instead of using only $\mathrm{CO}_{2}$ as the inactive gas, we also tested an acetylene mixture. As a byproduct, we saw that an evaporation from a freezing trap caused some fractionation, so the acetylene initially reached the cavities of the counter in a higher proportion than the $\mathrm{CO}_{2}$ (Olsson et al. 1962:247). It lasted hours until the mixing was complete as determined by a stable counting rate.

It was desirable to use a proportional counter without end effects. This was achieved by a construction with a movable end. The movement could be measured with a carefully calibrated screw. By subtraction of short-counter results from long-counter results (the end screwed out), the end effects were eliminated. It was necessary to extrapolate the measured activity to zero level of the threshold in the electronics. By relating the half-life results to the reciprocal pressures, we concluded that no wall effects could be detected. A 4th modern determination of the half-life, $5660 \pm 30$, was suggested by Bella et al. (1968).

\section{ISOTOPIC FRACTIONATION AND EARLY DISAGREEMENTS IN REPORTING RESULTS}

Isotopic fractionation is due to translation, rotation, and vibration energies and their proportionality to the masses of the isotopes. In nature, this is of importance for light elements like carbon with the weights 12,13 , and 14 . The isotopes thus behave slightly differently in chemical and physical processes. The fractionation for ${ }^{14} \mathrm{C}$ is almost exactly double that for ${ }^{13} \mathrm{C}$ (Craig 1954:133). Carbon of terrestrial plants is lighter than that of the air; the plants are depleted in ${ }^{14} \mathrm{C}$. When $\mathrm{CO}_{2}$ is dissolved in water, the ${ }^{14} \mathrm{C}$ is enriched. Numerous results are given, e.g. by Wickman (1952) and Craig (1953, 1954). The deviations from a mean value are small and expressed as \%o deviations:

$$
\delta^{13} \mathrm{C}=\left(\text { Ratio }_{\text {sample }} / \text { Ratio }_{\text {standard }}-1\right) \times 1000
$$

The interpretations by Wickman and Craig differed but both scientists found that most of the ${ }^{13} \mathrm{C}$ values for terrestrial plants hovered in 2 ranges. Some "anomalous" values also existed according to them.

Experiments were performed by absorbing carbon dioxide in barium hydroxide to get an explanation of the mechanism. Craig said that an enrichment factor depended on a thermodynamic process 
and a kinetic process. This is depicted by Vogel (1960). If gaseous diffusion is the rate-controlling step in photosynthesis, it would determine the fractionation of the plant, but the rate of chemical reactions must be considered. Anyhow, some factor in the different types of plants is affecting the fractionation. It is interesting to see that Craig also wanted to consider a direct assimilation of bicarbonate as indeed suggested earlier. The "anomalous" plants were still difficult to understand. Direct assimilation of ions by roots remained as a mechanism for fractionation. These questions are discussed together with reservoir effects.

About $40 \mathrm{yr}$ ago, there was a breakthrough in the understanding of the fractionation by plants when the photosynthetic pathways were studied. Troughton (1973) summarized this at the conference in Lower Hutt. There are variations of $\delta^{13} \mathrm{C}$ within plants, in leaves and wood (see e.g. Leavitt and Long 1982), and also between different chemical constituents as cellulose and lipids. The environment may also play some role. A histogram for $\delta^{13} \mathrm{C}$ in terrestrial plants shows a bimodal distribution correlated with the pathway of carbon metabolism. Most common are plants with $\mathrm{C}_{3}$ metabolism with $\delta^{13} \mathrm{C}$ around $-27 \%$ - assimilation according to the Calvin cycle. Those with $\mathrm{C}_{4}$ metabolism hover at the value $-14 \%$ and assimilate according to the Hatch-Slack cycle. An example is Zea mays. Then, we have CAM (Crassulacean acid metabolism) plants, succulents having $\mathrm{C}_{3}$ and $\mathrm{C}_{4}$ metabolism. Submerged plants get their carbon from bicarbonate, dissolved $\mathrm{CO}_{2}$, or $\mathrm{CO}_{2}$ released from the sediment.

\section{Libby, Craig, Deevey, and Carbon-13, in the 1950s}

Libby (1955:8) knew that carbon isotopes will be fractionated when $\mathrm{CO}_{2}$ is incorporated in organic matter. The figure given was $25 \%$ o more ${ }^{13} \mathrm{C}$ in inorganic matter than in the biosphere. Thus, ${ }^{14} \mathrm{C}$ would be depleted with $50 \%$ in the biosphere compared with a carbonate. Still, for years very little attention was paid by ${ }^{14} \mathrm{C}$ daters to the fractionation and the spread around a standard value as given by Wickman $(1952)$ and Craig $(1953,1954)$ and others. Deevey et al. (1954) measured ${ }^{13} \mathrm{C}$ in hardwater lakes to investigate the problems met when dating lake sediments. The range for ${ }^{13} \mathrm{C}$ in marine algae and non-marine carbonates seemed wide. In the first approximation, one would expect that half of the carbon derived from the atmosphere and half from old carbonate. $\mathrm{CO}_{2}$ may, however, be furnished by decaying organic matter or from old sources, e.g by volcanic action or a series of processes. The source must always be considered (Oana and Deevey 1960). A normalization based on the $\delta^{13} \mathrm{C}$ value was needed.

\section{Rare ${ }^{13} \mathrm{C}$ Normalizations, Confusion, and Error Quoting}

Olsson $(1959,1960)$ had the possibility to get mass spectrometer measurements done for her and she normalized essentially every result for the deviation from a standard and even insisted on publishing the deviations and continued doing so until the laboratory was closed. A typical spread is depicted by Olsson (1960). The original standard was replaced by the internationally accepted standard as described in the 3rd list (Olsson et al. 1961). Östlund (1959) and Östlund and Engstrand (1960) also normalized their results using ${ }^{13} \mathrm{C}$ results, not given in the lists except for 5 tree-ring samples, although this has not always been the habit, later on, in the Stockholm laboratory. Nydal (1959) in Trondheim wrote that he did not correct for fractionation. Stuiver and Deevey $(1961,1962)$ normalized the activity of a set of geochemical samples using ${ }^{13} \mathrm{C}$. The values are given; Oana and Deevey (1960) also published ${ }^{13} \mathrm{C}$ values.

Olson and Broecker (1959:3) mentioned that their ${ }^{14} \mathrm{C}$ wood standard, after ${ }^{13} \mathrm{C}$ normalization, had a different ${ }^{14} \mathrm{C} /{ }^{12} \mathrm{C}$ ratio than the standard based on oxalic acid. They suggested how to express variations of natural ${ }^{14} \mathrm{C}$ activities, discussed some terms, and gave an equation. Unfortunately, this 
equation was in error and a corrected formula was later given by them (Broecker and Olson 1961) as well as in an editorial statement in Radiocarbon $3 .{ }^{13} \mathrm{C}$ values were given by them in measurement lists on samples with known age, to mirror the influence on certain samples by the atmosphere.

There have been different opinions whether an error in the ${ }^{13} \mathrm{C}$ determination should be included in the calculation, and whether an error should be estimated when no such determination is performed. Similarly, it was discussed whether the uncertainty in the half-life should be included. Barker and Mackey (1959:82), for instance, wrote that they, missing mass spectrometer facilities, included an error of $\pm 80 \mathrm{yr}$ for isotopic fractionation. Another dubious habit was that errors smaller than e.g. 100 yr were increased by rounding the error to that value as a minimum. Otlet (1979) wrote correctly that one should doubt the meaning of error terms in published dates, and Callow et al. (1965) set out a full error term. Unfortunately, this is of little value, since they mixed their statistical estimate with a figure of \pm 80 for the de Vries effect (see below). They quoted the statistical uncertainty from a 20week period and that from $\delta^{13} \mathrm{C}$ and dilution, if actual, but included this systematical uncertainty of $80 \mathrm{yr}$. All of their results in their list were given with uncertainties $\geq 90$. Whenever the original value was not given, but a manipulated one, the chances to compare similar results to find age differences and make corrections later on were unfortunately lost. The intention might have been to supply a trustworthy date to a customer. This fact should have been given in a discussion besides the value based on measurements.

Sometimes it is possible to use an estimate of the ${ }^{13} \mathrm{C}$ content to obtain a realistic correction. It has also been a question whether mass spectrometer analyses could be afforded. Lerman (1973) reported that an analysis of Radiocarbon volumes 1-13 revealed that only $20 \%$ of the laboratories had included at least $1{ }^{13} \mathrm{C}$ normalization (up to 1971!).

Using the literature, Burleigh et al. (1984) summarized $\delta^{13} \mathrm{C}$ values from the period $1970-81$, excluding those from peat because of inhomogeneity, molluskan shells because of the diversity of species and locality, and soft tissues of humans and tree samples because of known problems with laboratory fractionation. Wide ranges are obvious and, especially for bone collagen, a skewed distribution is observed.

By combustion of sample remains, Lerman et al. (1970) were able to apply new $\delta^{13} \mathrm{C}$ normalizations to values given by de Vries (1958) instead of the old doubtful ones. The branches of the curve were then merged together. Years later, Deines (1980) published an elaborate study on the isotopic composition of reduced organic carbon.

Polach (1973:693) writes: "Within all dating laboratories ... it is the procedure to take an aliquot from a fully expanded sample, the $\mathrm{CO}_{2}$ gas generally being allowed to fill the mass spectrometer vial at the same time as the bulk $\mathrm{CO}_{2}$ storage and volume measuring vessel." I would recommend our procedure: the bulk storage should first be filled by allowing the gas expand from a trap, then the vial should be filled from this well-mixed gas. This is based on the experience of slow mixing, gained at the half-life determination. Jansen had indeed pointed out that the gas sampling procedure also could certainly contribute to observed variations (Polach 1973:692).

\section{ACTIVITY VARIATIONS AND THE FIRST COMMON STANDARD}

\section{First Attempts}

In a joint article in Radiocarbon, Willis et al. (1960) illustrated the possibility of a varying ${ }^{14} \mathrm{C}$ activity in the atmosphere by dating tree rings of known ages. Such variations were already documented by de Vries (1958) and even foreseen by Münnich (1957) who presented ${ }^{14} \mathrm{C}$ ages, remarkably dif- 
ferent from the true ages. de Vries assured that he believed in the results from Heidelberg. Samples, tree rings of Sequoia gigantea, were dated in the 3 involved laboratories - some in one, some in two, and one in all three-to get a common pre-industrial starting point, AD 1859. Besides confirming the existence of variations, the exercise was an early example of cross-checking. As seen from earlier cross-checks, we again were reminded to be careful in interpreting single dates even if the claimed accuracy is very good. Suess (1986:259-60) wrote that Libby originally did not believe in de Vries' wiggles and that this was unfortunate for the research. Suess also related the view around 1970 that the cause for the ${ }^{14} \mathrm{C}$ variations was the ${ }^{14} \mathrm{C}$ production through modulation of the cosmicray flux by solar activity. He presented a diagram with ${ }^{14} \mathrm{C}$ ages determined at Belfast in good agreement with those from La Jolla back to 4000 BC. Suess (1968) discussed the matter.

\section{Consensus Regarding a Standard and Presentation of Dates}

In 1959 in Groningen, an oxalic acid standard from National Bureau of Standards (NBS) was adopted as a new standard to replace all the local wood standards used in early days. The relations between these were soon determined in several laboratories. A measurement in 1958 (Broecker and Olson 1959:113) indicated good agreement with $95 \%$ of the activity of this oxalic acid. As a consequence of the knowledge of carbon fractionation and the possibility of fractionation in the laboratories, it was necessary to compare the ${ }^{13} \mathrm{C}$ values. The results from 13 laboratories were related to the PDB standard (Craig 1953:57) and presented by Craig (1961) in Radiocarbon 3. Apparently, some fractionation had occurred during handling, so measured activities had to be normalized. A high yield at preparation normally reduces the fractionation correction. Instead of using 1958 as the reference year, 1950 was chosen, although some confusion following this was apparent. The standard determined upon was thus $95 \%$ of the activity in 1950 for oxalic acid, ${ }^{13} \mathrm{C}$-normalized to $-19 \%$. The decision, again discussed at Nobel Symposium 12, was quoted by Olsson (1970:17) who at the same time discussed related problems. Since the activity of a sample is reduced, by decaying, with the same percentage as the standard, the ${ }^{14} \mathrm{C}$ age will be given before 1950 written as BP (before present).

\section{Problems at Conversion of Oxalic Acid to $\mathrm{CO}_{2}$}

Craig (1961) made a remark that a histogram of the $\delta^{13} \mathrm{C}$ values in his table revealed a non-Gaussian distribution, which could be expected from incomplete combustions. When gas from the same combustion was measured more than once (duplicate samples), the $\delta^{13} \mathrm{C}$ values agreed internally very well. A laboratory, La Jolla, had recombusted the gas, $\mathrm{C}_{2} \mathrm{H}_{2}$, used for counting. The value differed very much, but Craig wrote in a note that fractionation should not occur in that step. He also wrote that the spread in most laboratories seemed to correspond to a range of $5.5 \%$ for $\delta^{13} \mathrm{C}$, thus, in the order of $1 \%$ for ${ }^{14} \mathrm{C}(80 \mathrm{yr}$ in age). It may be worse for samples like wood with a range of $10 \%$ in $\delta^{13} \mathrm{C}$.

The ${ }^{14} \mathrm{C}$ community was worried, however, when it later was disclosed in some laboratories that the fractionation could be severe for oxalic acid during combustion. Polach (1973) presented figures on count-rate spread for all methane and all benzene preparations as histograms as well as the correlation between $\delta^{13} \mathrm{C}$ values and standard deviations of the count rate. Normalization to $-19 \%$ did not bring, in several cases, the activities to acceptable values for the standard. Grey et al. (1969) demonstrated that wet combustion of oxalic acid by means of potassium permanganate in acid solution yielded heavier $\mathrm{CO}_{2}$ the later in the process they collected the aliquots. Although the complete process gave $-19 \%$, the final aliquot gave $+61.5 \%$. Kim (1970) applied wet combustion and Lowdon (1970) dry. Lowdon found that an incomplete combustion, intentionally $\sim 60 \%$ yield instead of the 
normal value close to 95 , gave $\delta^{13} \mathrm{C}$ of about $-27 \%$, but that dry combustion normally was a safe method. Valastro et al. $(1977,1979)$ described an improved method for wet oxidation and Calf (1978) a procedure for preparation of benzene. The 2 latter papers give a summary of what was learned about fractionation during chemical reactions like the ones described. Nehmi (1980) applied wet oxidation. To this can be added that Otlet and Slade (1974) preferred dry combustion because of less scattering and negligible fractionation. Otlet (1979:259-60) furnished details. Meanwhile, I burned 18 oxalic acid aliquots by dry combustion. I was concerned about the large surface area from all the grains and recalled the adsorption of $\mathrm{CO}_{2}$ measured at the half-life determination. As a consequence, I flushed the sample for an extra long time in the combustion tube before starting the combustion. Our samples were $\delta^{13} \mathrm{C}$ determined in Stockholm until 1982, thereafter in Gothenburg, and lastly in Uppsala. Besides that, Mook measured 4 of our oxalic acid samples, yielding $-19.3,-19.2$, -19.6 , and $-19.4 \%$, respectively, besides the first one yielding $-19.1 \%$. Some 69 anthracite samples, out of 105 burned, yielded as a mean of $-23.1 \%$ o (Olsson 1986a). As a result, the uncertainty for the samples measured in Sweden decreased from 1-1.5\% to 0.5\% (Olsson and Osadebe 1974; Olsson 1986a). A final collocation of all results should therefore await an analysis to determine the small bias seen between the laboratories.

Polach and Krueger (1973) gave further evidence for fractionation of oxalic acid and suggested sucrose as a material for a new standard.

\section{Some Cross-Check Samples}

After Libby's et al. tests of the method on archaeological samples of known ages, it was natural to test the results from a laboratory against those from others. A widespread exercise was started when the number of laboratories in the Radiocarbon list reached 36. One third of these dated at least 1 sample out of a set of 3, submitted by H Tauber (Ruds Vedby), C Cortesi and F Bella (Lago di Nemi), and H de Vries (St Walburgkerk). Original results were given by Olsson (1959:100) with references from 1953-9. Later on, some results were added and others recalculated (Olsson 1991a) after normalization to the new common standard, oxalic acid, and when possible corrected according to the Index (see below). Polach (1973:698, Table 6) derived an intermediate list and, from this, he extracted the age limits for the 3 samples, calculated the ranges with standard errors from results given by the daters and the ratio between the range and the error. Before doing so, he should have discussed the risk for errors because of the technique. Half of the extreme values used were obtained by using the solid-carbon technique for activity measurements. Polach mentioned the pretreatment and gave an example in his Table 5. An additional result was given by Dresser (1985:340).

Interlaboratory cross-checks have been an important tool in quality assessment. At the ${ }^{14} \mathrm{C}$ conference in Lower Hutt, the question was raised why it was necessary to perform such checks, when we had samples for modern activity and suitable background samples. But discrepancies in measurements revealed that they were justified.

Many limited cross-check projects were performed later, and some others with many participants.

\section{The Standards}

The PDB standard is a Cretaceous belemnite, Belimnitella americana, from the Peedee formation in South Carolina. ${ }^{14} \mathrm{C}$ dates are given with the ${ }^{13} \mathrm{C}$ content expressed in the PDB scale, now often replaced by VPDB (V standing for Vienna). PDB and VPDB are virtually identical, but the use of VPDB as a standard implies that the measurements have been calibrated through NBS 19 (Consultants' Group Meeting on Stable Isotope Reference Samples for Geochemical and Hydrological 
Investigations, Vienna, September 1985). VPDB is nonexistent and NBS19 is obtained from a slab of white marble:

$$
\delta^{13} \mathrm{C}_{\mathrm{NBS} 19 / \mathrm{VPDB}}=+1.95 \% \text { 。 }
$$

Before a standard is close to be exhausted, a new substandard has to be selected and related to the old one. To reduce the work of recalibration, a standard sample should be available in large amounts. It must also be homogenous. A drawback with oxalic acid is that it had been regarded to be difficult to burn to a pure $\mathrm{CO}_{2}$. The $\mathrm{CO}_{2}$ can be used again and again in gas-filled proportional counters.

\section{ANU Sucrose and Other Possible Standards Discussed in 1972}

ANU sucrose was manufactured under stringent conditions from sugar cane grown in 1969 to 1971. It is available in enormous quantities and is granular. Bannister and Damon (1973) proposed the usage of a wood sample. Instead of the wood used by the Lamont laboratory, they chose the Hitchcock Tree from Arizona, a Douglas fir (Pseudotsuga menzieii). The wood was from AD 1846-55, thus pre-industrial. It was given a careful, but rather mild, pretreatment, removing about one fifth of the sample, and finally yielded 22 samples, each about $40 \mathrm{~g}$. A preliminary report is given by Polach et al. (1973) on Arizona 1850 wood, oxalic acid, and ANU sucrose.

A report on fractionation of oxalic acid and ANU sucrose samples was given by Polach and Krueger (1973). Polach (1979) and Currie and Polach (1980) reported on the correlation of the ${ }^{14} \mathrm{C}$ activities of the 3 standards.

\section{The Half-Life and Resolution of 1965}

Libby early on calculated a mean value of $5568 \pm 30 \mathrm{yr}$, but the new value of $5730 \pm 40 \mathrm{yr}$ was adopted in 1962, at the conference in Cambridge, as a better estimate and should be used for age corrections in geophysical measurements. The old value should be used at normal age calculations. This decision was repeated at the Pullman conference in 1965. One reason was that people otherwise could be unsure about what half-life was used. It was seen, however, that many users preferred to recalculate dates to be expressed in the longer half-life. Much confusion can indeed be seen in literature from the 1960s. Another reason was that we very well could get a new half-life determination. New recalculations should cause confusion.

The resolution approved in 1965 read thusly:

The Sixth radiocarbon conference meeting at Pullman, Washington, on June 9, 1965, under the general title 'International Carbon-14 and Tritium Dating Conference' recommended in some detail the question concerning the half-life that would be most useful in expressing radiocarbon dates. The consensus of opinion favored the retention of the previously used half-life of 5568 years (1). The reasons for this decision were based in the main on the desire to avoid the confusion which would arise should the many thousands of published dates require revision. It was also recognized that there are discrepancies between the radiocarbon chronology and other chronologies which would not be corrected by a change in half-life.

It was recognized that the value 5730 remains the best available half-life for the decay of radiocarbon. Those who wish to do so may continue to convert the published dates by multiplying by the factor 1.03 (2).

Paul E. Damon

Johann C. Vogel

Eric H. Willis

Frederick Johnson, Chairman 
A summary of the use of oxalic acid as a standard was given on p 17 in Nobel Symposium 12. There was a consensus on using the value 5568 for age calculations also at business meetings at some following conferences from 1972. As long as the calibration tables or curves are calculated with the same value, there is no reason whatsoever to include any contribution from the half-life to the uncertainty in the calibrated age. But the value 5730 should be used for age corrections needed to calculate $\delta^{14} \mathrm{C}$ and ${ }^{14} \mathrm{C}$ values.

The ${ }^{14} \mathrm{C}$ ages are now given in ${ }^{14} \mathrm{C}$ yr BP (before $\mathrm{AD} 1950$ ), calculated with the half-life 5568 and $95 \%$ of the activity of NBS oxalic acid in $1950, \delta^{13} \mathrm{C}$-normalized to $-19 \%$. The sample activity should be $\delta^{13} \mathrm{C}$-normalized to $-25 \%$.

Even if Radiocarbon in the editorial instructions in 1961 stated that $5568 \mathrm{yr}$ should be used, it is seen that $5568 \mathrm{yr}$ as well as $5570 \mathrm{yr}$ is used in dating lists.

With time, the supply of the original oxalic acid standard sample was too small, so new oxalic acid samples, and new substandards, have been taken into use. Other substandards have also been considered.

\section{NEW STANDARD RELATED TO THE ORIGINAL ONE}

A new standard was prepared from French beet molasses from 1977 and checked in a few laboratories (Cavallo and Mann 1980), discussed at the Heidelberg workshop (Stuiver 1980) and results given in Mann (1983). The old oxalic acid was now called SRM-4990 and the new one RM-49. In Seattle, it was decided that the new oxalic acid should be normalized to $-25 \%$ and the ratio between activities of the two should be 0.7459 (Stuiver 1983).

\section{REJECTED SUGGESTION}

To allow subtraction of $1950 \mathrm{yr}$ but indicate that the result was not given AD or BC, although calculated with the half-life 5568, it was suggested by English archaeologists (editorial comment in Antiquity 1972:265) that we should introduce lower case: bp, bc, and ad. This had been discussed for some years and finally, at the conference in California in 1976, disapproved by a majority of the participants (Proceedings, 1979, p xii; Olsson 1977). The English delegates seemed unconvinced that such an introduction would be confusing.

\section{Erroneous Conversion to AD or BC Results}

On request from some subscribers to Radiocarbon, the editors (ES Deevey and RF Flint) of Radiocarbon 15, unfortunately endorsed subtraction of 1950 from the BP value to get, what they wrote, the age $\mathrm{AD}$ or $\mathrm{BC}$. They thus neglected what was known about variations in the ${ }^{14} \mathrm{C}$ activity of the atmospheric $\mathrm{CO}_{2}$. For example, I had a "private" discussion with Dr Flint about that in connection with the conference in Pullman in 1965. Not until 1977 was such a subtraction discontinued in Radiocarbon.

\section{The Index}

As a consequence of adopting the new standard in 1959, many old values had to be corrected and a special issue (Radiocarbon Measurements: Comprehensive Index, 1950-1965) was published in 1967. All laboratories were asked to check their lists and give their new values, after correction. Unfortunately, there was a column with 1950 subtracted (cf. California proceedings, 1979, p xii). 


\section{COLLECTION, PRETREATMENT AND RESERVOIR AGE}

Advantages and disadvantages with plant material in ${ }^{14} \mathrm{C}$ dating, from a botanical point of view, were surveyed by Godwin (1969). Many problems, discussed for decades, were foreseen by researchers already in the 1950s and 1960s, e.g. pretreatment of charcoal (de Vries and Waterbolk 1958:1555).

\section{General Aspects}

Concerns about the value of ${ }^{14} \mathrm{C}$ dates on lake sediments were expressed by Iversen already in 1949 according to Oana and Deevey (1960:253). This was based on the fact that aquatic plants could use bicarbonate deriving from limestone. Two years later, Bartlett (1951) warned against calcareous deposits in and on plants of Potamogeton, Carex, and algae, and humified material soluble in hydroxide, deriving from rotten roots in peat. The chemical pretreatment should start with an acid to remove the carbonate. He also listed bioturbation and other disturbances, due to mechanical causes. Godwin (1969) discussed the materials used for ${ }^{14} \mathrm{C}$ dating and pointed out problems not yet thoroughly examined, like the photosynthetic mechanism, contamination from raised bogs, roots, emergent or submerged plants in lakes, erosion, hardwater effect, burrowing animals, and perturbation due to floating islands. He also briefly stated that there were difficulties with soil. Misassociation is also a source of error. Already in 1951 he briefly mentioned some problems. One was the possibility of bacterial influence (Godwin 1951:306). Geyh et al. (1974) looked into the question of bacterial activity causing ${ }^{14} \mathrm{C}$ results to be unreliable. Thus, the pretreatment of samples has a long history, partly related by Olsson and Kaup (2001:810). Pretreatment of samples aims at getting samples that really can date what should be dated. Samples like charcoal, wood, peat, and shells should initially be inspected to allow discarding foreign and suspect material. This may mean scraping the surface or, as for sediment cores, removing outer parts that were in contact with the corer, which might have been greased. Roots are generally younger than the surrounding deposits and may be removed chemically from charcoal (Haynes 1966). Even if roots and rootlets are removed, e.g. by sieving or picking from a sediment, some may already have decayed contributing some younger humus material. Geyh (1979) discussed storing of sediments and possible errors deriving due to long-term storing and showed that it was advantageous to freeze cores.

The question about displaced material should preferably be discussed before the pretreatment is performed. For wood, we have problems with driftwood. Siberian logs transported by rivers and then out in the sea may be thrown up on shores, e.g. of Svalbard or Iceland. Shoreline displacements have been determined using logs, shells, and also bones. But due to storms, such samples may be deposited behind storm ridges (Birkenmajer and Olsson 1971:32-3). Some logs may be deposited in bogs and used much later as fuel or raw material for constructions. For Icelandic finds, it was customary to avoid species not grown on Iceland. Wood may also have been brought there on board ships or derive from ship wrecks. Because of reusing, or generally, that some time may have elapsed between the time when the exchange with the atmosphere ceased, collection and usage, one can get somewhat too old ages for wood thought to date an event.

Burrowing animals can mix a top sediment more or less completely. The age may appear to be almost the same down to a few $\mathrm{cm}$. Thus, the sediment is dated too young at some depth, at the mixing depth and below that, and too old at the top (Olsson 1983 and references therein). An extrapolation to the top may yield too-low ages. Shells have been displaced by upfreezing, by washing from a level to a lower one at negative shoreline shift, by pushing of glaciers. 
Donner and Jungner (1980) dated shells in a project for sea-level changes, and from this study, it is apparent how important the question of the origin is. The formation of the marine deposits was considered and postdepositional changes were excluded. During a regression, the ${ }^{14} \mathrm{C}$ age sequence may reflect the real sequence as well as the occurrence of species. Shells from some bottom sediments were from death assemblages. Shells in gravels could have been redeposited together with the gravel, but at sites with gravel accumulation at the peak of transgression, the shells may date the accumulation.

\section{Wood}

For wood samples, it might be desirable to know if a sample represents certain tree rings. It should be checked whether bark is left. This should be removed since it may contain material from several years. This was seen by Olsson et al. (1969:542) on trees felled in 1967. The insoluble (INS) fraction of the bark had a mean activity $(330 \pm 10 \%$ o) indicating material partly grown before 1962 , since in 1967 they had declined to $600 \%$ and in 1962 it had reached a value of about $300 \%$. The acetone extract $(191 \pm 11 \%$ o) derived from radially moveable material.

Resinous components were sometimes extracted by using organic solvents, but these had to be removed afterwards, since they contain carbon. This was accomplished by washings with hot water, a long-time evaporation process, but not to dryness. Another method, used by many labs, is to extract cellulose, although cellulose is used to designate a variety of products. Even lignin was used.

It was shown by Wilson et al. (1963) that resin in sapwood could have a higher activity than cellulose from the same ring. This was further discussed at Nobel Symposium 12 and especially at the conference in 1976 (Cain 1979; Long et al. 1979; Olsson 1979a) and by Olsson (1980a) and Olsson and Possnert (1992). The resin can be radially transported. If this resin ever is used as a nutrient was an open question. The atomic bomb effect was high enough to easily be detected in the resinous product in some tree rings from pre-bomb times. This effect is seen a few decades before the bomb, time-dependent on the species. Nutrients stored in roots are used in spring and, thus, a slight memory effect is a reality.

\section{Remarks on Normal Pretreatment and Special Samples}

The reservoir effect is a deficiency of ${ }^{14} \mathrm{C}$ in reservoirs, especially in waters. It can vary with time and the results at ${ }^{14} \mathrm{C}$ measurements can be counteracted by, for example, erosion due to agriculture. Erosion results mostly, however, in contribution of older material. Photosynthetic pathways, species, the part of the plant, location, and contamination are factors influencing the measured activity. The choice of sample, mechanical and chemical pretreatment, and reservoir effects are thus closely related. For a long time, an $\mathrm{HCl}$ treatment was applied to remove carbonate. A hydroxide treatment (with e.g. $\mathrm{NaOH}$ ) was applied to extract humus products after a thorough water wash to remove $\mathrm{Ca}^{2+}$ ions, in order to avoid precipitated humus products from the solution. de Vries and Barendsen (1954) demonstrated the usefulness of such a $\mathrm{NaOH}$ extraction. It is recalled that it is not only humic acid that is extracted during $\mathrm{NaOH}$ treatment. In the past, the insoluble remains (INS) was the fraction dated, especially for peat, whereas the soluble part (SOL), after being precipitated using $\mathrm{Ca}^{2+}$ ions or an acid, often was the fraction used for dating (dy). Concerns were expressed early on for humic acid moving downwards. Often, the insoluble fraction of dy contains old inorganic material as graphite. Varved clay, containing a mix of autogenic and allochthonous material, is a typical example of a sample contaminated by transported material (Hörnsten and Olsson 1964; Olsson and Kilichi 1964). Another reason for different ages of deposits may be decaying material. Lake waters have been affected by humus from nearby bogs, and aged water has been supplied by inlets and 
wells. Thus, the reservoir effects can vary between different parts of a lake. Several fractions of the water mass from a lake, a nearby bog (its fen and its lagg separately), and a raised bog were investigated and yielded widely spread activities. All these samples were from the period 1981-3 (Olsson 1986b). The hardwater effect was shown to be serious in some lakes (see below). Even the outlet of extremely hardwater into seawater in fjords may cause a local reservoir age. Olsson (1999a) summarized such complications, experiences, and pretreatment improvements from the 1960s and later for deposits. Fulvic acid is dissolved at the pretreatment. The humin, as defined in much of the literature, is insoluble.

The fact that some sediment samples appeared much too old because of transported material, infinitely old graphite, or only somewhat older sediments, had to be investigated. We found that graphite needs a higher temperature and a stronger oxygen stream than normal samples (Olsson et al. 1972:259) at combustion, but still the yield may be low. Fractionated combustion, a separation into gas obtained at degassing, at normal combustion and a forced combustion were tested on samples as summarized by Olsson $(1972 \mathrm{a}, \mathrm{b})$. Wet oxidation with $\mathrm{KMnO}_{4}$ of a sample was also shown to yield too old an age, much older than the humus product (Olsson et al. 1969:532), indicating some content of old carbonaceous material, probably graphite. For a wet combustion of graphite, the yield seemed higher than at normal combustion (Olsson 1991b:32). The pretreatment may also be improved, when allochthonous material is suspected, by applying wet combustion. Once in Uppsala at the frothing stage, small particles were lifted and these were determined in Helsinki to be amorphous coal (Olsson 1968). Since graphite cannot be dissolved during $\mathrm{NaOH}$ treatment, it will be left in the INS fraction. Erroneous results on sediment samples from areas with graphite can, thus, often be explained if dated on the INS fraction. The SOL fraction must be very pure. A general warning was given to be careful when interpreting results of samples with low carbon content. The ash content after combustion may help, but it was seen that the ash to a great extent may derive from remains of diatoms (Olsson and Florin 1980:299).

For wood, it was seen by Olsson et al. $(1969,1972)$ that the chemical treatment is critical. The length of the $\mathrm{NaOH}$ extraction must be long enough to allow a satisfactory removal (Olsson 1980a). We preferred an initial extraction followed by several washes and after that an "overnight" extraction. Glad and Nydal (1982) removed very little of the extractives in a 5-min $\mathrm{NaOH}$ treatment in their test of the pretreatment. In earlier studies, they had used 5-15 min. In the literature, this treatment is often called AAA (acid, alkali, acid) treatment, although time for extraction as well as concentration, temperature, and size of used chips mostly are omitted.

\section{Hardwater and Softwater}

Olsson et al. (1969:541-2) and Olsson (1983) doubted the dates from e.g. Öland because of the hardwater and also saw that different parts of submerged plants could have different ${ }^{14} \mathrm{C}$ activities due to their origin. Håkansson (1979) found that the depletion of ${ }^{14} \mathrm{C}$ relative to the atmosphere was about the same for submerged plants from 1974 and 1975 in southern Sweden for calcareous and non-calcareous lakes, except for 1 non-calcareous lake exhibiting a much larger depletion than the others. He wrote that this could be due to a slow exchange of the $\mathrm{CO}_{2}$ between the atmosphere and water.

Rootstocks of Nuphar and Nymphaea, developed over many years, had stored nutrients, which later were used for the growth of the plants before the floating leaves assimilated $\mathrm{CO}_{2}$ from the atmosphere (Olsson 1983). Plants from the atomic bomb era were used. (This was further discussed by Olsson and Kaup 2001). Olsson et al. (1983) continued the research on the hardwater lake Säynäjälampi. Donner et al. (1971) had obtained dates that were too old, because of the hardwater 
effect, to judge from results for certain levels dated elsewhere. Later, Olsson and Vasari (1995) demonstrated a slow response to radioactivity changes in the atmosphere. The conclusion that the activity today does not necessarily yield a value of the reservoir age was thus confirmed.

Throughout the years, efforts were made to emphasize that also softwater lakes could have reservoir ages. It is the ratio between the isotopes which is important, not only the hardness of the water. The hardwater effect is simply a special case (Olsson and Florin 1980; Olsson 1991b). For evaluating the quality of the results, the ash content and composition are of interest. Low organic content means a great risk for inorganic material contaminating a sample.

\section{Shells}

Shells were regarded as bad dating material in the early days of ${ }^{14} \mathrm{C}$ dating (Anderson and Libby 1951). Already in 1959, a check for possible surface contamination was introduced (Olsson 1959, 1960; Feyling-Hanssen and Olsson 1959-60; Olsson and Blake 1961-2). Mostly, the shells were leached with $\mathrm{HCl}$ to remove the outermost part. Then, the leaching was continued to yield a 2nd and sometimes a 3 rd and maybe even a 4th fraction. For the result, such a surface contamination is more harmful for thin shells and shells with a pitted surface. We hesitated to accept the dating of sample B43 because of its pitted surface (Olsson and Blake 1961-2). The age difference between the innermost fraction (13\% of the shell) and that outside this (14\%) was determined to be $>2 \sigma$.

Autogenic foraminifera shells, Pteropoda and Coccolithophores, deposited in cores from the western Mediterranean Sea, collected for various investigations, were contaminated by aeolian-supplied material from Africa. It was difficult to separate the components in the mixture by size (Olsson and Eriksson 1965). This fact, and the additional risk for contamination during storing and handling, initiated a study using recent or "infinitely" old shell material; different size fractions and dispersion media; moist and dry atmosphere; and even ${ }^{14} \mathrm{C}$-rich gas as a tracer. Some samples were leached by acid to yield outer and inner, or even intermediate, fractions. Decontamination was tried by flushing or evacuation to, if possible, remove adsorbed $\mathrm{CO}_{2}$. The final conclusion was that storing "infinitely" old shell material (about 44-74 $\mu \mathrm{m}$ ) in slightly moist atmosphere could cause samples to be dated at a finite age instead of an infinite age. The earlier commonly used dispersion liquid, aqueous ammonia, must be avoided. Recommendations had now to be given to use slightly acidified water or boiled deionized water, and to store old shell samples in evacuated vessels or in an inert gas until dated. Warnings were raised against materials from museums and sediment cores stored wet (Olsson et al. 1968). It was not possible to remove the adsorbed $\mathrm{CO}_{2}$ at the tested decontamination experiments. The gas from the outer parts could be dated to get arguments in a discussion of a possible contamination, but mostly it was of little value for the age determination. A contamination of this type cannot be detected by X-rays, although such can reveal recrystallization. As discussed by others, carbonate may be deposited on the surface and in pores to make the separation into outer and inner fractions of no use, or even make the situation worse.

In connection with contamination problems, especially for shell dating but also for dating in general, diagrams were published giving errors due to contaminants with different ages. Such diagrams were published in several papers from 1960 onwards. Vita-Finzi and Roberts (1984) X-rayed shells to determine whether there had been a recrystallization from aragonite to calcite, which would not necessarily mean contamination. Infillings of aragonite may be a contamination. With X-rays and SEM, the leaching could be controlled.

An example of a serious contamination, probably due to exchange with groundwater, was given by Olsson (1973). Samples from an anthropogenic shell mound were collected above and below (1 
sample) the groundwater level, and fractions obtained by stepwise leaching were dated. A significantly lower apparent age was determined for the shell sample below the groundwater than for 2 samples of the same species above it. The age difference between the 2 fractions of the contaminated shell was very close to $2 \sigma$, the outer $35 \%$ being younger than the inner $25 \%$, after removal of $40 \%$ of the shells. In the same investigation, charcoal, scraped from the surface of shells, dated a few hundred years younger than the brackish-water shells. This is a typical example of the technique for determining the reservoir age of waters.

\section{Bones}

The first bone dates were not reliable (Taylor 1987). Bone samples were not even listed among samples to be used. The early chemical treatments were similar to that for other types of samples and were not successful. Apatite dating was sometimes successful. The aim soon became to date collagen to eliminate contaminants. The main part of bone material is carbonates, as inorganic hydroxyapatite crystals. About half of the organic part may consist of collagen, a protein composed of amino acids, other proteins, etc., and fat. The amount of collagen decreases, however, with time and may be less than $1 \%$. Collagen does not exchange carbon with the environment according to what is presently known. The word "collagen" is not proper; instead, words describing the distinguishing trait should be used.

Contaminants as mosses and rootlets are often found in the pores of bones besides other humus remains. The $\mathrm{Ca}^{2+}$ ions must be removed to prevent the humic acid precipitating. The final step may consist of a dissolution in hydroxide, but some "collagen" was lost earlier in the treatment. An EDTA (sodium salt of ethylene diamine tetra acetic acid) treatment aims at demineralization of the sample as tested in Groningen and Uppsala with reliable results in the 1960s and 70s (Olsson et al. 1974; El-Daoushy et al. 1978). Fear was expressed that this would lead to contamination by the carbon in the EDTA, but this could be overcome by repeated careful washings. The drawback was that the washing was time-consuming, although not very laborious. Centrifuging was successful (Olsson 2000). Initially, we used pieces of bone but started to grind the samples to allow effective penetration of the liquids. Dialysis was tested but abandoned. The treatment with $\mathrm{HCl}$ was also tested in Uppsala, and with certain precautions also successful. (Taylor [1987:60] has a schematic description.) The Longin (1971) method was widely used but often in some modified form. Brown et al. (1988) were able to increase the yield and consequently improve the purification using ultrafiltration. Treatments in some laboratories with other methods have been developed, partly to suit AMS measurements and partly to remove contaminants. Gillespie and Hedges (1983) isolated and used chromatographic purification of amino acids from bones and tooth collagen. The method was also used for lipids from sediments and cellulose and glucose from wood, paper, parchments, and textiles. Gurfinkel (1987) wanted to be able to produce reliable dates by learning about the contaminants. He compared 4 methods and used good-quality, weathered, spongy bone. Since his samples were Arctic, the collagen was well preserved. Measurements had to be interpreted with caution, especially since a weathered sample seemed to be affected by contaminants difficult to remove. Stafford et al. (1987) isolated still more fractions and confirmed that bone material easily yield wrong ages because of contaminants. They recommend XAD treatment to remove humates and to isolate individual amino acids from hydrolyzed protein or purified peptides.

\section{Aquatic Plants}

Aquatic plants cause problems, as understood already before the ${ }^{14} \mathrm{C}$ method was devised (see Craig 1954:132), since they were shown to be able to utilize $\mathrm{CO}_{2}$ and also bicarbonate in photosynthesis. Various plants may behave differently. The moss Fontinalis is almost unable to use bicarbonate, 
according to the survey by Steemann Nielsen (1946). He studied Myriophyllum and gave references back to 1907 and 1910. Wium-Andersen (1971) studied Lobelia dortmanna utilizing $\mathrm{CO}_{2}$ diffusing into the roots up to the leaves and there used for photosynthesis. Sand-Jensen and Prahl (1982) continued the studies stressing the gas transport via the lacunae-oxygen down to the roots and rhizomes; $\mathrm{CO}_{2}$ from roots to leaves. Søndergaard and Sand-Jensen (1979) studied Littorella uniflora. They used ${ }^{14} \mathrm{C}$ to determine the time-course in their experiments. The individual plants behaved differently depending on the root development in sand and mud. The sand plants had a larger area. Stirring, affecting the $\mathrm{CO}_{2}$ concentration around the roots, was positive for the uptake. In the light of the different pathways and waters, Smith and Walker (1980) concluded that an unstirred layer of the liquid, where the plants grew, is an important factor in the rate limitation of $\mathrm{CO}_{2}$ fixation as well as the assimilation of $\mathrm{HCO}_{3}{ }^{-}$. Species like Myriophyllum spicatum, Potamogeton lucens, Ceratophyllum demersum, Elodea, and Chara corallina were included in the discussion of diffusion of $\mathrm{CO}_{2}$ and still others in the membrane transport of $\mathrm{HCO}_{3}{ }^{-}$. Also, the question of the possibility of $\mathrm{C}_{4}$ photosynthesis in aquatic plants was raised. Calder and Parker (1973) studied the fractionation of ${ }^{13} \mathrm{C}$ in bluegreen algae and reported that increasing availability of $\mathrm{CO}_{2}$ resulted in greater fractionation above a minimum level of $0.2 \%$ in air.

\section{${ }^{14} \mathrm{C}$ SAMPLES, DATES, AND THE RESERVOIR EFFECT}

Since the relative ${ }^{14} \mathrm{C}$ content in waters is usually lower than in the contemporaneous atmospheric $\mathrm{CO}_{2}$ (the reservoir effect), the sediments and organic materials in waters will as a rule be dated too old. The apparent age will also be affected by contamination and effects discussed above and below and by the sources-as dissolved $\mathrm{CO}_{2}$ and bicarbonate. Leaves falling into a lake may cause the apparent age of the sediment to be lower in parts near the shores than in the midst of the lake. The supply of dissolved humus from a nearby bog or fen may cause the sediment near the shore to appear too old. Similarly, emergent plant existence will affect the ${ }^{14} \mathrm{C}$ content of sediment in the actual part of the lake.

Overbeck et al. (1959:42-3) warned against downward movement of humic acid in peat. As a consequence, for years laboratories preferred dating the INS fraction of peat. When results from SOL and INS fractions were compared and analyzed, the results revealed, however, that the SOL fraction often yielded the most reliable age. The INS fraction was often affected by old material. A question to be raised is, for example, whether graphite is present in the actual area. The ash content after combustion is thus of interest in discussions whether the dates are reliable or not, but the warning that the ash might contain diatom remains has to be remembered (Olsson and Florin 1980).

Olsson (1999a) summarized what had been written about the reservoir effect and how it had been determined throughout the years. She also stated that the hardwater effect is a special case of the reservoir effect and that a reservoir effect always is expected even in softwater lakes, although mostly less obvious than in hardwater lakes. It is the ratio between ${ }^{14} \mathrm{C}$ and the stable carbon isotopes that determines whether there is a reservoir effect or not.

The apparent reservoir effect for sediments was early determined using 2 methods. Willkomm and Erlenkeuser (1973) presented results between 0 and $1600{ }^{14} \mathrm{C}$ yr for 22 lakes. Olsson and Florin (1980) used extrapolation to the surface but also applied a correction for the density due to the lesser amount of compaction close to the surface than deep in the core. They also compared the dates for a distinct pollen-analytical level in a lake with that in an adjacent peat deposit. To avoid the problems with reservoir effect, roots and contamination by graphite in sediments, terrestrial macrofossils (as leaf remains) were picked and dated in some laboratories. Pine needles are rather resistant and 
can be present at wrong levels as contaminants. Pollen, dated using the modern AMS technique, are also resistant, and may be helpful but also cause troubles as contaminants. When land uplift is studied in connection with the transition from salt- to brackish- to fresh-water sediment, another possibility for studies of the reservoir effect opens up. Erosion, bioturbation, and penetrating roots should be considered. Checks with ${ }^{210} \mathrm{~Pb}$ to prove that the top sediment is recent together with dates from layers somewhat down in the sediment may yield an approximate reservoir age (Olsson et al. 1983).

In hardwater areas, there is an apparent risk for the reservoir effect to decrease with time due to leaching, which Geyh et al. $(1970,1971)$ demonstrated for Lake Schleinsee.

Under favorable conditions, yearly lamina allow ${ }^{14} \mathrm{C}$ dates to be compared with absolute dates. This is similar to wiggle-matching between tree-ring dates and sediment. It is then recalled that the pattern for sediment is somewhat smoothed.

The classical explanation for the marine reservoir effect was given using a simple box model. The deep ocean is a big mixed reservoir, almost 100 times bigger than the surface mixed layer. When some $\mathrm{CO}_{2}$ is exchanged between the boxes (a slow process), the percentage for the deep layer is correspondingly lower. The residence time in the deep layer is long enough to allow some radioactive decay to occur, so that the deep water will appear older than the surface layer, and this will appear older than the atmosphere.

For the marine reservoir effect of organic material, an age comparison with well-dated contemporaneous terrestrial material was commonly used. The same applies to well-documented samples from museums. Some whale species can cover large areas; thus, integrated results can be obtained. For shells, there is a depth dependence in their habitat. A latitude dependence for shells along the Norwegian coast was determined by Mangerud and Gulliksen (1975) based on shells, further discussed by Olsson (1980b) together with more samples from Nordic countries. A summary of results based on simple models was given by Birkenmajer and Olsson (1998). For sea animals, the interpretation must include a consideration of their own age and that deriving from the food as fish and seals. Polar bears may eat berries and meat (e.g. from musk ox). Eskimoes (Inuits) collecting birds that were not fed on fish from the sea besides normal seafood will exhibit a lower reservoir age than if they feed from pure seafood. Tauber (1979) measured the activity and $\delta^{13} \mathrm{C}$ of several marine mammals, tested normalization to the accepted value $-25 \%$ and to $0 \%$. He also tried to correct for the industrial effect. He discussed samples from AD $1750 \pm 50 ; 1886 ; 1900 \pm 50$ and later.

Complications arise at fjords that have hardwater supplies with low relative ${ }^{14} \mathrm{C}$ content (HeierNielsen et al. 1995). Another problem considered is displaced samples (see above), e.g. from higher levels, deposited samples behind storm ridges, in shell mounds or even mollusks carried alive by birds collecting food with the intention to eat the flesh at another place (Feyling-Hanssen, private communication; Olsson 1993a:217).

The early results for the marine reservoir age were thus based on samples from rather recent times, but box models have been used for discussing the exchange between atmospheric $\mathrm{CO}_{2}$ and surface seawater and to the deep water. A smoothing effect is considered for the transfer between the boxes. Olsson (1980b:664) "aimed to arrive at a reservoir effect that is not affected by short-term fluctuations of radiocarbon in the atmosphere." The age range could then be extended (Stuiver et al. 1986b). Their work started with a box-diffusion model from the 1970s. The mixed layer, $\sim 75 \mathrm{~m}$, and the deep layer exhibit an age difference determined on planktonic and benthic organisms. The reservoir age, $R$, could then be handled as varying with time, $R(t)$, and the biosphere could be described as 2 reservoirs. The differences between the regions were plotted on a map. 


\section{ORIGIN OF CARBON AND SPECIAL TYPES OF SAMPLES}

$\delta^{13} \mathrm{C}$ values mirror the diet. Tauber $(1981,1983 \mathrm{a})$ demonstrated that humans from coastal sites had a ${ }^{13} \mathrm{C}$ content similar to that for eskimos, and he concluded that an important share of the diet was fish, overlooked by the archaeologists while sieving. Bender (1968) and Lowdon (1969) wrote about isotopic fractionation in corn. The $\delta^{13} \mathrm{C}$ of collagen from people in North America (van der Merwe and Vogel 1978) revealed a change in diet to corn (Zea mays). This was dated in the normal way.

Bumsted (1984) stated in her thesis that we still knew too little about the human carbon cycle. The collagen is inert as far as we know today. Her schematic illustration was: menu to meal, to dietary composition, to nutrition, to midden. She presented evidence that $\delta^{13} \mathrm{C}$ could be different for males and females and that the distribution was not normal. This could be due to some biological factornot necessarily the food. In all studies, the sex, age, and health should be given, if possible. In past literature, scrutinized in her study, it was also confirmed that the chemistry used could differ from laboratory to laboratory. The components of the diet will vary during the life cycle. The enrichment goes in several steps and we know too little about the metabolism. Since ${ }^{13} \mathrm{C}$ reacts slower than ${ }^{12} \mathrm{C}$, the tissues get different $\delta^{13} \mathrm{C}$, not only dependent on the diet. Another factor is that the relative share between, for example, lipids and protein varies. The meat could derive from bison eating $\mathrm{C}_{4}$ grass. The percentage of Zea mays cannot be given with any accuracy because it was not known well enough.

Bada et al. (1987 and references therein) argued that some tissues are considered to be inert. Monkey eye-lens nuclear proteins is one example and narwhal tusk growth layer organic material is another. The tusk derives from Northern Baffin Island, Canada, but we do not know the migratory and feeding behavior. The authors wrote that the activity was depleted and that Tauber (1979) similarly found a depleted activity in tissues from polar marine mammals and birds. But 3 of Tauber's samples were from Greenland ( 1 was a polar bear) and 1 from Denmark. Tauber also included 2 Eskimo samples from Greenland and 2 polar bear samples, measured in Lund (1 from Spitsbergen and 1 from eastern Greenland). The $\Delta^{14} \mathrm{C}$ values fell in the range from -56 to $-73 \%$ (apparent age range: $430-590{ }^{14} \mathrm{C} \mathrm{yr}$ ). Tauber also tried to make a correction for industrial effect. It was clear that these figures mean a lower apparent age than for the tusk from Canada. Olsson (1980b) has a still lower apparent reservoir age for Scandinavia than Tauber for Greenland (the 2 sets of results normalized in the same manner). It would have been a natural step in the Bada et al. (1987) discussion of the tusk samples to check with the values given by Stuiver et al. (1986b:1017). Their 3 values, deriving from Trondheim, give results from Ellesmere Island that are significantly lower activity than for those from NE Greenland.

\section{Carbon Isotopes: Growth Area and the Origin of Samples and Products}

Bergquist (1964) made experiments indicating a small absorption of $\mathrm{CO}_{2}$ also by roots. The question was then if such an effect could affect normal dating of terrestrial material. Broecker and Olson [1960:712, 720-1] also reported different activities for contemporaneous samples. They wrote that the possibility of uptake by roots should be discussed.

Results from Arizona on various samples from Montezuma Well, a sink in freshwater limestone with hardwater (Damon et al. 1964; Haynes et al. 1966), showed such differences in activity that the possibility of uptake by roots had to be considered further. Remains of Potamogeton illinoensis, modern Chara sp. (from 1963), modern Potamogeton illinoensis (from 1964), and water had activities, between about $4.7 \%$ and $11.6 \%$ modern. Tufa carbonate (organic and inorganic) as well as a 
turtle were similarly deficient in ${ }^{14} \mathrm{C}$ in comparison with modern emergent Scirpus and Populus fremonti leaves. The latter 2 were significantly lower in activity than 2 grass samples.

Inspired by earlier results, Olsson started experiments by growing tomatoes in buckets outside the laboratory (Olsson 1972a:19, 1979b; Olsson et al. 1972). There were more results not published. To 2 of the buckets, ${ }^{14} \mathrm{C}$ and ${ }^{12} \mathrm{C}$ were added, deriving from the half-life measurement and the calcareous island Öland, respectively. Different parts of the plants and fractions of these (SOL and INS) were analyzed. The INS fraction of the roots in the ${ }^{12} \mathrm{C}$ bucket indicated a slightly lower activity, but the SOL a significantly lower activity than normal. The INS fraction of the roots in the ${ }^{14} \mathrm{C}$ bucket had a significantly higher activity than normal.

Leaves from Salix and Betula collected on the same day in June 1968 at 2 very different sites-1 close to Uppsala with softwater soil and 1 on Öland with hardwater soil—and measured 6 samples with $\Delta^{14} \mathrm{C}$ results within the range $588 \pm 8$ to $623 \pm 9 \%$ o (Olsson et al. 1972). No extreme activity was thus detected here, considering the limits of uncertainty. Nor could any difference due to the hardwater ground conditions be detected by the Finnish laboratory measuring modern Betula leaves, and leaves from the annular emergent plants Carex and Phragmites communis from the shores of a calcareous pond at Loppi, south Finland, according to a study in Otaniemi (Heikkinen et al. 1974; Heikkinen and Äikää 1977). Tauber (1983b) studied the possible uptake using tree rings of Fagus sylvatica from an extremely calcareous area in Zealand, Denmark, and compared the results with those from an area with normal conditions as well as with activities given by Stuiver (1982). The time span was from AD 1850 to 1940 . Tauber could not detect any significant difference between the activities.

\section{Carbonates as Eggshells, Mortar, and Marlekor}

When confronted with material such as ostrich eggshells, questions were raised as to whether food, contaminants in the food, or shells given to improve the digestion could contribute to an apparent age. Long et al. (1983) surveyed the literature and performed feeding experiments, compared the minor organic fraction, mainly protein, with the carbonate fraction. The experiments were organized so that the carbonate was "dead" and the organic part of the feed "modern." In one case, the carbonate fraction of the feed was $\sim 22 \%$ and in another $\sim 11 \%$. The organic fraction of the eggs was ${ }^{13} \mathrm{C}-$ depleted with $10 \%$ relative to the feed, but the carbonate fraction had approximately the same ${ }^{13} \mathrm{C}$ content as the feed. The shell carbonate was supposed to derive from dissolved inorganic carbon in the blood plasma, and this derives almost completely from the feed. Although there are questions not yet resolved, the conclusion is that ${ }^{14} \mathrm{C}$ dates on eggshell carbonates require little or no correction.

Freundlich et al. (1989) dated ostrich eggshells, without ${ }^{13} \mathrm{C}$ normalization, and charcoal. As a mean, there was an age difference of $400 \pm 50 \mathrm{yr}$, the eggshells being younger. But with an expected $\delta^{13} \mathrm{C}$ value close to 0 for the carbonate, a normalization would bring the results to the same value. The authors write that the $\mathrm{CO}_{2}$, according to the literature, is metabolic and generated in the shell gland - the site of the egg formation. The $\delta^{13} \mathrm{C}$ values should thus be dependent on the feed, mostly $\mathrm{C}_{3}$ in Germany and $\mathrm{C}_{4}$ plants in the USA. Fish might also be given and the $\delta^{13} \mathrm{C}$ values affected.

Mortar dating was tried with some success in various laboratories, including in Gif-sur-Yvette (France), presented at the 6th conference in 1965, and in Austin (Texas), presented at the 9th in Los Angeles and La Jolla. The basic assumption is that limestone is heated to release $\mathrm{CO}_{2}$ and yield lime $(\mathrm{CaO})$, which is mixed with e.g. sand, the aggregate. Then, water is added to yield a carbonate together with $\mathrm{CO}_{2}$ absorbed from the air, the hardening. Complications such as an incomplete release of $\mathrm{CO}_{2}$ from the initial carbonate, a slow or even not complete hardening process and any 
carbonate, e.g. marble, added together or instead of the sand are obvious. Some laboratories failed totally. An improvement was seen when the mortar was separated from the aggregate (Folk and Valastro 1979). A few years later, van Strydonck et al. (1983) and Sonninen et al. (1985), using essentially the same method, had problems and stressed the importance of selecting good samples. Surface mortar can dry in weeks, but mortar inside a thick wall may need years or even $>100 \mathrm{yr}$.

Carbonates may be dissolved and redeposited as marlekor. We got a 60-g sample from Beatelund (Olsson 1993a:215-6), a Quaternary concretion $\sim 1.4 \mathrm{~cm}$ thick, which looked like a slice of bread with a surface of about $6 \times 3 \mathrm{~cm}$, but did not know whether it had grown from a thin central layer or kernel or whether it represented successive horizontal layers. It was said to contain $74 \% \mathrm{CaCO}_{3}$. We treated the sample as a shell, thus initially leaching it with $\mathrm{HCl}$ to clean the surface and then continued the leaching to get 4 fractions-30\%, 30\%, 17\% and $23 \%$, respectively, as measured by the yield of gas—dated at $6730 \pm 130,7590 \pm 120$, and $7660 \pm 140$ (remeasured at $7850+280 /-270$ in another counter after 3 months), and $8230 \pm 120$, respectively. The 4th fraction was obtained after a break when the remains $(13.5 \mathrm{~g})$ were slightly cleaned by leaching before continuation. The $\delta^{13} \mathrm{C}$ values were the same within the limits of error at the time for measurements, in 1971. The carbonate was apparently deposited during a very long time. The "cake" did not date the actual level in the clay. The fractions should, in this case, not be regarded as strictly outermost to innermost.

\section{Lichen}

For lichen (see Olsson et al. 1984), we must consider the symbiosis between fungi and algae and that the nutrients derive from the latter, but also that the water involved may have a reservoir age. Lichen deteriorates easily and the material may be reused. At seashores, the droppings from birds, enhancing the growth, may contribute low-activity carbon. Lichen living on rocks enhance the weathering. In the case of available carbonates, their activity may be affected. Besides these effects, one should also consider that the assimilation, and thus the growth, for long-lived fruticose lichens takes place in the upper parts. The apparent age may therefore vary for different parts of a single specimen. Some lichen species are long-lived with a lifetime of hundreds of years, while others are short-lived with lifetimes amounting to only tens of years or less. When dating our samples, we used the organic fraction, about 1/4 of a sample, mainly the lichen Stereocaulon, after normal pretreatment. Very little was extracted as SOL fraction. Most of our samples from Kongsøya, Svalbard, hovered around 775 ${ }^{14} \mathrm{C}$ yr with a spread of $\pm 175{ }^{14} \mathrm{C}$ yr, although $\sigma$ calculated from the individual uncertainties indicated an expected spread of $\pm 25{ }^{14} \mathrm{C}$ yr. This indicates a period. One sample measured on the whole lichen (top, base, and size fractions) indicated a spread of $\pm 140{ }^{14} \mathrm{C} \mathrm{yr}$, although the individual uncertainties indicated $\pm 85{ }^{14} \mathrm{C}$ yr. Another sample dated on different parts indicated a range of 345 ${ }^{14} \mathrm{C}$ yr - almost $4 \sigma$. Still another sample did not get any difference in apparent age between top and base. Two living lichen samples must have started growing well before AD 1950 to judge from a low, although apparent, atomic bomb activity. The long-lived type seemed confirmed. The top of one of them seemed younger than the mean for that sample confirming the growth pattern given above. Two check-samples from Uppland, Sweden, on another species, collected in 1983, indicated a lifetime of about $5 \mathrm{yr}$. The conclusion, considering the results and the calibrating curve at that time (Stuiver 1982), is that it seemed impossible to calibrate the results in a normal way. What age with what uncertainties should be subtracted before the calibration?

\section{${ }^{14} \mathrm{C}$ in Plants and Alcoholic Beverages: Forensic Research, Local, and Regional Effects}

The global increase of ${ }^{14} \mathrm{C}$ activity in the atmosphere due to nuclear tests (the atomic bomb effect) has been used as a tracer in various studies and is therefore of great interest. Besides $\mathrm{CO}_{2}$ assimilated 
by plants, stored in tree rings, recently absorbed in a basic solution on a tray, or forced through a solution and on molecular sieves, one can use ${ }^{14} \mathrm{C}$ assimilated by plants and stored in well-documented beverages and in that way go further back to study also the industrial effect (the Suess effect). Walton et al. (1967) wrote that whiskey could be used for this documentation. Malt whiskey is produced using barley with known origin and yeast acting as a catalyst; the contribution of carbon from water should be negligible. For blended whiskey, however, the origin may be less known. Similarly, the origin and age of vintage wine should be well known. Baxter et al. (1969) found a good correlation between their malt whiskey values and those from Copenhagen on Danish cereals, although the growth period may be slightly different. They also got values back to the 1930s. The Glasgow group then extended the period back to 1897 and the area to Portugal, France, and even Australia using vintage wine (Baxter and Walton 1970). Seeds of various species and known ages have also been used. Plant values also reflect the daily variations due to assimilation and respiration.

A risk for falsification is apparent; thus, $\delta^{13} \mathrm{C}$ and $\delta^{14} \mathrm{C}$ measurements have been used in forensic contexts. de Vries measured ${ }^{14} \mathrm{C}$ content to distinguish material made from modern plants from articifally made from coal. He tested, for example, the 2 isotopes on vanilla. Determinations on wine may reveal an admixture of synthetic alcohol without ${ }^{14} \mathrm{C}$. Similarly, Dauchot-Dehon and Heylen (1979) could detect a falsification of vinegar from 1970. Two samples out of 9 had much too low an activity to be produced from wine. When the cheaters learned to avoid old carbon, the laboratories could check whether the ${ }^{13} \mathrm{C}$ content could reveal the origin of the suspect product. Similarly, Evin et al. (1983:62) could, with $\delta^{13} \mathrm{C}$ and $\Delta^{14} \mathrm{C}$ values, determine that a series of samples indicated synthetic products mixed with natural components.

Beverages have also been used to check whether any ${ }^{14} \mathrm{C}$ has been released from the various nuclear installations in amounts harmful for people. Concerns were expressed in the 1970s and 80s about this possibility. A study from Bratislava began in 1967 (Povinec et al. 1986) that allowed a longterm comparison with activities determined by the Heidelberg laboratory. In the Bratislava area, the activity was 3-4\% lower than for the so-called clean air. In the atmosphere surrounding the heavywater reactor, starting at the end of 1972 , the ${ }^{14} \mathrm{C}$ activity increased, with $\sim 25 \%$ as a mean but varied a lot, when the atomic bomb effect had declined to around $300 \%$. Results using wine samples normally agree with atmospheric samples from the same area when the growth period is considered. No extra ${ }^{14} \mathrm{C}$ released at the test in 1945 of the fission bomb could be detected.

Even if researchers speak about a clean-air ${ }^{14} \mathrm{C}$ level, this is hardly achieved because of the use of fossil fuels, devoid of ${ }^{14} \mathrm{C}$, and emission of ${ }^{14} \mathrm{C}$ from reactors, depending on the type of reactor. The level has been recorded all over the world since the end of the 1950s. The Heidelberg laboratory collected not only $\mathrm{CO}_{2}$ but also hydrocarbons at boiling water reactors (BWR) and pressurized water reactors (PWR) (Levin et al. 1980; Segl et al. 1983). $\mathrm{CO}_{2}$ is a weak source at PWRs, emitting mainly hydrocarbons. There is also little $\mathrm{CO}_{2}$ emitted from the soil. Mainly, ${ }^{14} \mathrm{CO}_{2}$ is emitted at BWRs. At the conference in Trondheim, there were contributions about release from the nuclear power plants in Yugoslavia and Czechoslovakia. Some results are given in Radiocarbon [31(3):747-85] from Switzerland, Hungary, Yugoslavia, Czechoslovakia, and Austria. The local input is generally low for samples collected during some years. Release of ${ }^{12} \mathrm{C}$ was studied in Poland for a few years at Kraków (Kuc 1986) and in Upper Silesian urban areas.

Since fruits seem suitable for samples from a well-defined year, hawthorn berries were chosen by Otlet et al. (1983) for studies of the dispersion at Sellafield. It was shown that apples were produced by photosynthesis in the surrounding leaves. Shoots and tree-rings may contain material from the previous year, especially in early spring, and grass has a short growth period. 


\section{Aerosols, Dispersion, and Possible Impact from Nuclear Installations}

The concerns expressed in the 1970s and 80s regarding the release of ${ }^{14} \mathrm{C}$ from nuclear installations affecting our health included the accumulated dose. To collect samples from earlier times, one used plant material as tree rings, but also alcoholic beverages of well-known origin.

Closely related to dose estimates are studies of dispersion of aerosols. That was done at National Bureau of Standards (now NIST) by Currie and coworkers and reported at ${ }^{14} \mathrm{C}$ conferences from 1976 and onwards. Determinations of nature, origin, dispersion, and occurrence are of importance, not only ${ }^{14} \mathrm{C}$. The ${ }^{13} \mathrm{C}$ content is of value, although limited, because of overlapping ranges for species. Since small samples are involved, small counters were developed, but the AMS technique has facilitated these measurements. The carbonaceous component is of special interest, because of its anthropogenic and natural origin. It may be gases affecting the greenhouse effect directly or indirectly by chemical reactions. Particles affect the albedo and the cloud formation. The size can tell us something about the origin.

McCartney et al. (1986) tried to test different box models from a 1-box model to the Oeschger et al. (1975) diffusion model to predict future individual and collective doses up to AD 2050. Then, ${ }^{14} \mathrm{C}$ releases and the Suess effect counteract each other. Although the net effect of a forest clearance has a small influence on the activity, it is an important factor in the global carbon cycle, and thus for the climate. The dispersion models had to be improved and therefore be studied together with meteorological data. Measurements on samples from the Sellafield area were of interest. The Gaussian plume atmospheric dispersion model was seen to predict values in agreement with observed ones for Cambrian grass samples, but the hawthorn values (Otlet et al. 1983) deviated (slope and extrapolation to infinite distance) in plots of activity as a function of the distance. This indicates a weakness in the model, or results or different release rates. The conclusion was that the release of ${ }^{14} \mathrm{C}$ from the Sellafield plant was significant, but the impact on the local population negligible, although the collective-dose commitment is large compared with that from other nuclides because of the long halflife.

\section{${ }^{14} \mathrm{C}$ and ${ }^{13} \mathrm{C}$ in Human Tissues and in Food}

The bomb effect was tested by Broecker et al. (1959) in lung tissue, blood, and respiratory $\mathrm{CO}_{2}$ and compared with that in the atmosphere. Apparently, the metabolism may play a role but also the food, since much of our food reflects the activity in a preceding year. Broecker and Olson (1960) in their discussions on differing activity results for contemporaneous tree leaves raised a question whether there could be a possibility for introduction of carbon via roots. They used a 10-box model with exchange between stratosphere and troposphere; troposphere and surface sea waters; Antarctic and Pacific and Indian deep water; and Arctic and deep Atlantic and Antarctic waters. The rapid increase of the stratospheric ${ }^{14} \mathrm{C}$ from 1958 to 1959 , due to Russian tests during the fall of 1958 , was suggested to be due to tests in the Arctic instead of in the equatorial Pacific. The authors predicted $\Delta^{14} \mathrm{C}$ values up to the year 2000 for the troposphere and surface water. They described how the bomb ${ }^{14} \mathrm{C}$ could be used as tracer in soil science, biochemistry, limnology, and oceanography.

The tests performed in 1961 and 1962 released about 2/3 of the energy since 1955. This has allowed transfer studies using various box models. Nydal et al. (1971) used a 5-box model where the biosphere was divided in half -1 with long residence time and 1 together with the troposphere. The authors also accepted a direct exchange between deep water and the troposphere plus part of the biosphere. Their measurements from 1962 to 1969 were made on hair from a boy, born in 1962, and total blood from 2 women, both $26 \mathrm{yr}$ old in 1963. In their diagram, they inserted results on human tissues from the Northern and the Southern hemispheres, given by other researchers. 
The results of the studies, in crude figures, was a delay time of about $1.4 \mathrm{yr}$ after the food was in equilibrium with the atmosphere and thereafter a mean lifetime of about $10 \mathrm{yr}$ in humans. This did not apply to bone and cartilage. Similar studies were done (e.g. Stenhouse and Baxter 1977). Details regarding the diet and the growth of tissues were considered. The marked difference in activity, at death in 1969, between tissues on one hand and bone mineral as well as bone collagen on the other, was documented by Harkness and Walton (1972) for a 37-yr-old woman.

The atomic bomb peak was used for dating the growth layers of gallstones. One must consider the delay for food from being in equilibrium with the atmosphere until it enters the blood and the lungs. The growth time for the chemical substances, mainly cholesterols and bile pigment, can then be determined by ${ }^{14} \mathrm{C}$ dating (Druffel and Mok 1983). When a stone is cut, concentric rings may be seen, which can be used when selecting samples for the dating. If the dates as a function of time can be correlated to an activity curve for diet plus residence time for blood, etc., as a function of time, the growth as a function of time can be determined. Druffel and Mok reported a stone growing for about a decade, until its activity maximum, but it apparently was dormant until the patient was operated in 1975 . The $\delta^{13} \mathrm{C}$ values went from -19.1 to -17.4 . I could detect a peak activity in a stone, the first one examined in Uppsala. The activity was well-constrained around the bomb peak. ${ }^{13} \mathrm{C}$ values ranged from -21.4 to -21.8 .

$\delta^{13} \mathrm{C}$ values for human tissues from males and females of varying ages and varying causes of death were given by Stenhouse and Baxter (1976:166-71) in connection with their ${ }^{14} \mathrm{C}$ values for the response to nuclear tests. The death years were 1971-3. Lyon and Baxter (1978) have a histogram on $\sim 80$ tissue samples with a range from about -21 to $-26 \%$. The authors cannot see any trend with the type, sex, age, or disease. Since replicate analysis indicate a precision of $\pm 0.03 \%$, there is a significant natural variability in the values. The other $\delta^{13} \mathrm{C}$ values obtained in connection with bombactivity measurements have given a similar spread but even some heavier carbon.

\section{Chernobyl: Regional Consequences}

The injection of radioactive gases and deposition of fission products immediately after the Chernobyl accident (26 April 1986) has given us a time marker seen in snow profiles. An increased ${ }^{14} \mathrm{C}$ activity was detected in various material close to e.g. Minsk. Fallout was reported early on from the nuclear plant Forsmark in northern Uppland, where they first feared an accident there but found that it was due to another source. The activity outdoors was indeed higher than indoors. At Studsvik, south side of Stockholm, they soon detected fallout. The radioactive cloud went towards the Baltic, Poland, Czechoslovakia, Austria, the Alps, United Kingdom, and even to the US. Where it rained, radionuclides were washed out and entered the food. We thought we had better collect samples for tracking any extra ${ }^{14} \mathrm{C}$. At Smara, east of Uppsala, I collected rhubarb grown until May 4. The plant was still like a ball, as small as an egg at the start but grew to $\sim 5 \mathrm{dm}^{2}$ at the end of exposure (Olsson 1989). Each of 3 fractions had a slightly higher activity than the atmospheric $\mathrm{CO}_{2}$. Since the general trend for the atmospheric activity was a decrease, this may be due to a memory effect for the 8-yrold rhubarb plant-using nutrients stored in the roots from foregoing year(s) as seen for trees in springtime. The weather was nice in Smara but rainy in Uppsala, where G Possnert collected 2 samples one after the other on 29 April (foggy and hazy conditions for the first sample and clear sky for the second) and one on 30 April (windy from the Atlantic) outside his office window, each for $1 \mathrm{hr}$. He measured the activity, and there was a marked difference in activity between the samples. Kuc (1987) collected $\mathrm{CO}_{2}$, routinely in 2-week cycles in Kraków on a molecular sieve. By inserting 3 additional 2-day samplings from 28 April to 5 May, he could ascertain an increase of $\sim 9 \%$ above the normal ${ }^{14} \mathrm{C}$ level in 1986 . It should be recalled, however, that this extra collection was performed at a height of $2 \mathrm{~m}$ instead of the normal one of $20 \mathrm{~m}$. 
The statistics for background and oxalic acid for the actual period February to August 1986 was quite good in my laboratory (Olsson 1988, 1989). The background showed a decreasing trend. We took precautions to prevent contamination of the floor by changing shoes for a rather long time before entering the laboratory. Pazdur and Zastawny (1987) got their counters severely contaminated by dust particles.

A student and I once tried to correlate extreme values with weather conditions according to notes given by those collecting our samples in Abisko and on Svalbard but failed at that time. I thought it might be some scavenging effect.

\section{Volcanic Effects, Tephrochronology, and Ice-Core Chronology}

Gases released at volcanic eruptions can directly or indirectly affect ${ }^{14} \mathrm{C}$ datings. Besides that, ash may be produced in enormous quantities and spread over large areas in directions determined by the prevailing wind. For example, ash from Katla, Iceland, was detected in AD 1625 outside Iceland; from Askja in 1875, detected by bare eyes in Stockholm; and similarly from Hekla in 1947 in Finland, thus easily detected by anybody. The tephra (ash layers) are excellent time markers. Pumice can float ashore and be used in land uplift studies. Microscopic studies of sediments can reveal many more layers. A new dating method, tephrochronology, designed by Thorarinsson in the 1930s was presented as a PhD thesis in Stockholm (Thorarinsson 1944), initially for Iceland. It was a chronology originally based on written sources as Landnámabók in Iceland and other sources in other countries, like that of Vesuvius, AD 79. It is recalled that an eruption occurred, as a mean, every $5 \mathrm{yr}$ in historic time in Iceland. Naturally, this chronology has been refined throughout time. The identification of the layers was first visual in field by color, grain-size analysis, stratigraphy, measurements of layer thickness, and then chemistry and refractive index and search for trace elements. ${ }^{14} \mathrm{C}$ was sometimes used for a crude estimate. Since the emitted $\mathrm{CO}_{2}$ is devoid of ${ }^{14} \mathrm{C}$, the gas might have caused some ${ }^{14} \mathrm{C}$ dates to appear older than expected to judge from known evidence. Libby and Libby (1973) discussed this possibility and concluded that such a dilution would have much less influence than the industrial effect on a global scale.

Trees exposed to $\mathrm{CO}_{2}$ diluted with $\mathrm{CO}_{2}$ from volcanoes will get rings appearing older than contemporaneous rings. A famous example was given by Sulerzhitzky (1970) for a 40-yr-old tree, charred and killed during an eruption. The outermost 8 rings appeared $1700 \mathrm{yr}$ older than the innermost 16 and the next 8 . The 8 rings from number 25 from the center appeared $800 \mathrm{yr}$ older than the innermost 25 . He detected a volcanic effect in several other samples, like gas, steam, and carbonates, even collected kilometers away from the source. Close to the source, the activity of the gas approached zero, although with a slight admixture of atmospheric $\mathrm{CO}_{2}$.

Chatters et al. (1969) published results from fumaroles, even in considerable amounts a mile away from the source. Figures for grass around some $\mathrm{CO}_{2}$ vents and that for gas from the vent indicated apparent ages of 13,000 yr or older (Šilar 1976). In an area with no eruptions in historical time but with abundant hot springs and mofettes, 2 gas samples had almost no ${ }^{14} \mathrm{C}$ (Saupé et al. 1980) and living plants apparent ages of a few hundreds to a few thousand years. Similar results were obtained by Bruns et al. (1980) from the Eifel area and from Palea/Thera.

In 1971, I was interested to know whether a volcanic effect might have affected the dates obtained for samples from Iceland, which seemed too old according to the tradition. A real opportunity was given at the eruption on Heimaey in winter 1973. Some results are summarized by Olsson (1979b; 1993a:218) and further discussed together with systematic studies in a lecture given in 1990 (Olsson 1997) on, among other problems, the volcanic effect on Iceland and other possible natural effects 
over a larger region. It was seen that in 1978 materials from Svalbard and Iceland had a lower activity than in Sweden; that emitted gas from the lava field could have less ${ }^{14} \mathrm{C}$ than the "normal" atmosphere; and that gas collected in the basement of a house was almost devoid of ${ }^{14} \mathrm{C}$.

Small pertuburations of the global ${ }^{14} \mathrm{C}$ activity are difficult to detect for the $1960 \mathrm{~s}$ and first years of the 1970s because of the seasonal variations of the atomic bomb effect. Olsson (1993b, 1997) has diagrams on some activity values in the north from 1975 to spring 1989.

Another chronology, the ice-core chronology, was also developed and used together with ${ }^{14} \mathrm{C}$ and tephrochronology. The basic principle is layer counting for the youngest part and the use of ice-flow models for the older part. Trace elements and isotopes show seasonal variations. Water with ${ }^{16} \mathrm{O}$ is more easily evaporated than that with ${ }^{18} \mathrm{O}$. When precipitated at e.g. Greenland, the heavier $\mathrm{H}_{2}{ }^{18} \mathrm{O}$ is enriched in the snow and thus $\mathrm{H}_{2}{ }^{16} \mathrm{O}$ in the vapor. As a consequence the ice-core technique can be used for climate studies like Dansgaard et al. (1970) demonstrated (e.g. Hammer et al. 1980, 1986). In 1987, a colloquium was held in Gothenburg to elucidate the problematic dating of the Thera/Santorini event. Acidity measurement had given $1390 \pm 50 \mathrm{BC}$ and frost rings $1626 \mathrm{BC}$ (LaMarche and Hirschboeck 1984). ${ }^{14} \mathrm{C}$ had also given a date earlier than that the archaeologists had favored. The discussion was partly on the question whether results, outliers, should be omitted or kept, but given with little weight. The date $1390 \mathrm{BC}$ was later ascribed to another eruption. A new ice-core value was published and available immediately before the colloquium started. It was $1645 \pm 7 \mathrm{yr} \mathrm{BC}$, but presented with a question mark (Hammer et al. 1987). In 1988, a scientific correspondence appeared in Nature (p 401-2) with contributions from Manning (1988); Hammer et al. (1988), and Cadogan (1988). The same year, Hughes (1988) writes that the estimated error limit given in 1987, $\pm 20 \mathrm{yr}$, should be used at comparisons with the frost-ring result and that this in turn suffered from an arbitrarily inserted year " 0. " The discussions went on for years in various journals.

\section{MEASUREMENT AND CALIBRATION: SOME CONCEPTIONS}

$\mathrm{H}$ de Vries tried to explain the variations of the ${ }^{14} \mathrm{C}$ concentration in the atmospheric $\mathrm{CO}_{2}$ (de Vries 1958) as a consequence of climatic changes, seen as advances and retreats of glaciers. These secular ${ }^{14} \mathrm{C}$ variations are commonly called the "de Vries effect." Are these wiggles or wriggles? We saw in the manuscripts for Nobel Symposium 12 that there was no consensus among the authors about that. The solution was to take a vote and the word "wiggles" won. In 1969, the word "wriggles" was, however, used by some participants according to the published discussion (p 309-11) after Suess' paper.

Lingenfelter and Ramaty (1970) studied the time-dependent variations of the production rate of ${ }^{14} \mathrm{C}$. They focused on the terrestrial and interplanetary magnetic fields affecting the galactic cosmic rays and fluxes of cosmic particles produced by solar flares and by variations of the local interstellar cosmic-ray flux produced by supernovas. The average production rate was determined to $(2.2 \pm 0.4){ }^{14} \mathrm{C}$ $\mathrm{cm}^{-2} \mathrm{~s}^{-1}$ for solar cycles from 1937 to 1967.

It was known that the ${ }^{14} \mathrm{C}$ production could vary with about $30 \%$, or even more, over an 11 -yr cycle. Box models for ${ }^{14} \mathrm{C}$ and the exchange between the atmosphere, mixed surface seawater, deep seawater, and biosphere were discussed and evaluated by many researchers. The exchange between the reservoirs of $\mathrm{CO}_{2}$ was a possibility to consider (Stuiver 1961, 1965). It is slow and with some delay (Revelle and Suess 1957; Bien et al. 1963). Inspired by de Vries, Stuiver (1961) studied the relationship between ${ }^{14} \mathrm{C}$ concentration and sunspot activity yielding short-term variations. These were superimposed on long-term variations, not yet understood (Stuiver and Suess 1966). The exchanges were explained in a simple way using an electrical scheme. The variations could also exhibit a small 
latitude effect but were described as a worldwide phenomenon. A table for the latest $2000 \mathrm{yr}$ was given by Suess and Stuiver with values, from La Jolla and Yale, adjusted to the oxalic acid standard. In such presentations, one should consider possible offsets between laboratories. A preliminary figure for that between La Jolla and Yale was expected and used, since La Jolla had wood (1870 to 1880) of a fir from Oregon as standard. Schove (1955) participated in the discussions and had estimated the sunspot number. The sunspot phenomenon was observed since over many years.

Another effect, the "Suess effect" or industrial effect or fossil-fuel effect was suggested (Suess 1953, 1955 ) and acknowledged since the 1950s. Suess used proportional counting with acetylene (1954). The industrial effect meant a lowering of the ${ }^{14} \mathrm{C}$ content in the atmosphere due to the use of fossil fuels. It could be expected to be locality or region dependent unless the mixing was not very rapid. It should be apparent from about AD 1850 and increase with time thereafter. The ${ }^{14} \mathrm{C}$ variations were superimposed on the de Vries effect. The mixing over the Equator is relatively slow, like that over the tropopause and that from the atmosphere to the mixed seawater layer. These are causes for the oceanic reservoir effect. The relative surface of seawater in the Southern Hemisphere is also larger than that of the Northern, so variations can be expected to be smoothed although follow similar patterns in the 2 hemispheres. Measurements had given that the activity for the Southern Hemisphere was $\sim 5 \%$ lower than that for the Northern. Box models were used in several discussions at Nobel Symposium 12. Bolin (1960) was a pioneer in that field. Fifteen years later, we got the very useful box-diffusion model (Oeschger et al. 1975; Oeschger and Siegenthaler 1979). Suess writes in 1955 that the exchange for $\mathrm{CO}_{2}$ with the ocean and the absorbed amount is greater than previously assumed. Many results on the Suess effect were published throughout the years before Nobel Symposium was held. Lerman et al. (1970) presented several new results from Alaska in the north to Argentina in the south. Until the mid-1960s, the known activities were mostly determined on counted tree rings and on some archaeologically known samples. It is evident, however, from discussion before, at, and after the Nobel Symposium, that some samples used for this purpose were not well defined. The dendrochronology and the ${ }^{14} \mathrm{C}$ chronology were then developed in close collaboration and that allowed calibration of the latter. The precision and age ranges were extended. Already in mid-1960s, the De Geer varve chronology, originally developed a century ago (see Fromm 1970), was used for crude estimates of ${ }^{14} \mathrm{C}$ activity variations. Stuiver included, in a lecture at Nobel Symposium 12, discussions on that chronology. It has later undergone several revisions concerning the connection to present time and in parts of the country (Cato 1985; Strömberg 1985 and references therein). A symposium on the matter was held in 1984 in Stockholm (see Boreas 1985 14[2]:97-137).

The 3rd effect to be studied was the atomic bomb effect - the production of ${ }^{14} \mathrm{C}$ during tests of nuclear weapons, which caused the ${ }^{14} \mathrm{C}$ content to increase with $100 \%$ at northern latitudes in Scandinavia in 1963 and 1964 but slightly less in the US at least in 1963. The resistance against the transfer between the different reservoirs, especially over the tropopause, was thought to be a reason for a latitude dependence. The tropopause moves in a vertical direction. The mid-latitude gap between the stratosphere and troposphere allows gases and particles to cross the barrier (Münnich and Vogel 1963 and references therein). This, together with a following diffusion northwards and southwards, were regarded to be the reasons for the summer maxima. The resistance against transfer over the Equator caused the activity to be much lower and show less pronounced peaks in the Southern Hemisphere than in the Northern. The difference decreased with time and was small already in 1967. From about AD 1973, the difference is hardly seen (Nydal and Lövseth 1983). The tropospheric activity was measured in several laboratories (e.g. Heidelberg, Trondheim, and Uppsala) in Europe. We saw a slight delay between Svalbard and Abisko, when the activity went up and that the 
peak at Svalbard seemed to be slightly lower than at Abisko. The stratospheric results were based on collection on molecular sieves and indicated a much higher activity than in the troposphere.

\section{Contamination in 1965 Due to a Limnological Experiment in Abisko}

The strange peak in the Uppsala values in 1965 was due to contamination (Olsson and Stenberg 1967:73-7) caused by a limnologist breaking the rules, on 25 April, for work in Abisko. Instead of being filtered in the main laboratory, the liquid in a bottle with an active sample, which had been exposed in the lake, was filtered in a small building, $150 \mathrm{~m}$ from the laboratory. On the roof of that small building, we had our sampler during exposures; the tray was washed and the liquid stored in this small building. We traced the possible contamination by scrutinizing the notes on the handling of our samples for Abisko and Spitsbergen, from preparation of the $\mathrm{NaOH}$ until the gas preparation. Our conclusion was that the reason for the main peak and the extra peaks was contamination via the sewage system and the air as a consequence of the filtering in "our" building.

\section{Conventional Measurement of Radiocarbon}

It was possible for Libby to detect natural ${ }^{14} \mathrm{C}$, in spite of its low activity, since enrichment of sewage methane was applied. He and his coworkers realized that the measurements for dating purposes must be performed in another manner since otherwise it would be too expensive. They built a heavy iron shield and installed Geiger counters in anticoincidence with their screen-wall Geiger counter, as Andersen (1936) did, to be able to measure low activities. The efficiency was low since the black carbon layer inside the counter wall had to be "infinitely thick." Besides that, this carbon was easily contaminated by radioactivity deriving from nuclear tests. The final step in the preparation was grinding in an agate mortar (Libby 1955:51).

A few laboratories used similar setups, but the method was soon obsolete and gas-filled counters were taken in use-in the start with low pressure. Early in the 1950s, it was shown in Groningen (de Vries and Barendsen 1953), Heidelberg, and Lower Hutt that sample $\mathrm{CO}_{2}$ could be used as counter gas in proportional counters at pressures above $1 \mathrm{~atm}$. It could also be avoided that the sample came in contact with the atmosphere after combustion. If Geigers were used, a quenching gas like $\mathrm{CS}_{2}$, together with electronic quenching, was needed. Two other gases were commonly used: acetylene $\left(\mathrm{C}_{2} \mathrm{H}_{2}\right)$ and methane $\left(\mathrm{CH}_{4}\right)$. Ethane $\left(\mathrm{C}_{6} \mathrm{H}_{6}\right)$ was also tested in Hannover (Geyh 1967). Is there any doubt how much carbon there is in ethane counting gas-how pure is the ethane? The gases are sensitive to electronegative impurities as determined in a few laboratories, e.g. by Brenninkmeijer and Mook (1979), so the purification was studied and improved. For example, oxygen, water vapor, sulphur dioxide, and nitrogen oxides had to be removed. They attach the free electrons to form slow negative ions resulting in less well developed pulses or pulses too low to pass the threshold. Even if $\mathrm{CO}_{2}$ is worst, the other gases need more chemistry and thus there is a greater risk for isotopic fractionation. Two or more carbon atoms in a molecule allows the possibility to use a lower pressure.

Tans and Mook (1979) discussed the gas amplification and sensitivity to electronegative impurities. The excited $\mathrm{O}_{2}$ releases the electron after a short time, $5 \times 10^{-12} \mathrm{~s}$, unless the $\mathrm{O}_{2}$ is stabilized by a collision with $\mathrm{CO}_{2}$ within that time. They stated, for example, that electrons close to the wall suffer more electron attachment than those close to the wire. They preferred quartz. Other details are given, including safety precautions in case the pressure is too low. The shield and electronics are described. The background is dependent on the filling pressure, but a memory effect was apparent even after 4 hr of pumping. It was not serious for oxalic acid because of the sequence chosen between the samples. Because of a barometric-pressure dependence of the background and the anticoincidence count rates, and because of the sample activity, the dead time varied to necessitate a correction. 
The hydrogen must be free from tritium. Even if high pressures can be used, the decays will create electronegative impurities. When measuring high activities, like during the half-life measurements, this was seen from changes of the characteristics for ${ }^{14} \mathrm{C}$ compared to those for background.

An early purification method was to absorb $\mathrm{CO}_{2}$ on hot $\mathrm{CaO}$ to form carbonate, let this cool down, remove some of the impurities by pumping, and then decompose the carbonate at high temperature. The heating in the laboratory was annoying and one of the causes that this method was abandoned (de Vries and Barendsen 1954). The purification was accordingly improved by de Vries (1956a). Another cause was radon, although radon also could derive from shells to be dated and the oxygen used for combustion as checked in Uppsala (Olsson 1979a, 1988). The sample gas was usually stored for weeks to overcome that problem. But in some laboratories, an $\alpha$ channel was installed in the electronics for checking or even correcting - a procedure that could be difficult. A batch of $\mathrm{CaO}$ caused radon problems, but a new one did not. de Vries (1957) even developed a method for removal of radon using the different volatility of $\mathrm{CO}_{2}$ and radon. This method was not commonly used, but we used that in Uppsala besides having an eye on an $\alpha$ channel. Radon could also be deriving from lead in the system. A new step, with active charcoal, was introduced later on in some laboratories.

Combustion bombs were introduced with the intention to give an alternative to the generally used combustion and purification method designed by de Vries (1956a). The bombs were rather well developed early in the 1970s (Burleigh 1973; Switsur 1973), although not commonly used.

There is a big variety of shapes of gas-filled proportional counters. In Bern, for example, the anticoincidence was separated from the main counter by a mylar foil. Since such a foil may have low mechanical stability and also absorb gas, which is difficult to remove, and to avoid a memory effect, the foil was replaced by wires. Using the common gas, the efficiency will be smaller than necessary. Small counters were used, for example, in Brookhaven and Harwell (see Otlet and Evans 1983 and references therein).

The configuration of the (anticoincidence) shield varied a lot. Libby's had the shape of an umbrella (Libby 1955:Figure 11) with a few extras below the main counter. Mostly, the Geigers were placed in a ring, as a tube, around the main counter (or counters). Because the anticoincidence counters often have sturdy walls, the geometry had to be considered. To avoid insensitive parts and as an extra precaution, some extra counters were often used to cover the walls. Other researchers having rather short anticoincidence counters were successful in placing extra anticoincidence counters at the end of the main counter. We checked that we had counters long enough by moving the main counter stepwise until the background was affected. In Groningen, 1 ring with Geigers seemed sufficient. As early as 1952, a heavy layer between the main counter and the anticoincidence counter was shown to reduce the background by absorbing gammas. Such a layer, independent whether it was lead or mercury, was also added in Groningen (de Vries and Barendsen 1954) and improved the background. It is interesting to study their background diagram for 6 months (their Figure 3), which de Vries wanted analyzed. He was critical of their own statement that there were no significant indications for variations.

The anticoincidence shield eliminates nearly $100 \%$ of the hard component of the cosmic-ray contribution to the background, and the heavy shield the greater part of the gammas, depending on the mass and thickness of the shield. The concrete around the shield is also of importance. Some radioactivity may derive from the laboratory walls. Underground laboratories (Oeschger et al. 1979, 1981; for a survey of low-level setups, see e.g. Gulliksen and Nydal 1979) were used. Concrete was even chosen as well as the material for the shield. The lead could often derive from church roofs or old guns, but the Swedish recent lead, Boliden B quality, was outstanding. Electrolytic copper was 
shown to have low contamination of radioactivity. Quartz was preferred instead of glass, which often contained potassium. Since scintillation counters are efficient in detection of gammas, the anticoincidence Geigers were replaced by scintillation counters in a few cases. Thus, the dead-time increased because of the many counts, but the volume of the setups could be decreased.

de Vries (1956b) studied the background dependence on the barometric pressure. Indeed, he asked me to help with that using the values from a barograph in a nearby drugstore. I simply tried a leastsquares analysis and thereafter a correction for barometric-pressure variations became a standard. When testing a gas (propane) containing hydrogen, without any precautions to eliminate the soft component of the cosmic rays, he got a higher background than he had with $\mathrm{CO}_{2}$. He also placed paraffin with boric acid on top of the shield and got a reduction of the background, but no reduction when this was replaced by lead. Lead on top of the paraffin improved the background. A paraffin isolator of the counter was removed and the background decreased. His conclusion was that paraffin with boric acid should be built in inside the shield. The most probable source for the barometric effect in conventional shields was the neutrons. Accordingly, we had a low barometric effect, which disappeared when we moved from top of a building to a position with 3 laboratory floors and an attic above the shield.

Liquid scintillation counting was developed more or less in parallel with gas counting but started later and in the beginning the development of the chemistry was the main interest, see e.g. Tamers (1966) and Noakes et al. (1966). Benzene $\left(\mathrm{C}_{6} \mathrm{H}_{6}\right)$ is commonly used as the sample solvent. $\mathrm{The}_{2} \mathrm{CO}_{2}$ is converted via a carbide to acetylene and this to benzene. The volume will be small. The necessary shielding, during scintillator counting, resembles that for gas-filled counters. Geyh (1973) compared proportional counters with liquid scintillation spectrometers. In 1967, Libby privately answered, when asked by a new student what method should be chosen, that a chemist should choose liquid scintillator counting but a physicist should choose gas counting, when establishing a new laboratory. The vials with the samples can be cycled to achieve automatic registration of a desired sequence for background, standard, and samples. Commercial equipment was developed. About 3 decades ago, the AMS measurement technique was developed, which is outside the scope of these historical ruminations (see Povinec et al., this issue, for a review of AMS developments, among other topics).

Thermal-diffusion isotope enrichment has also been applied (see e.g. de Vries et al. 1956; Grootes et al. 1975; Grootes 1977; Grootes and Stuiver 1979). Stuiver et al. (1978) and Erlenkeuser (1979). Whenever enrichment is used, the uncertainties and problems are usually discussed.

Bern scientists (Oeschger et al. 1979 and references therein) discuss the rise-time discrimination method; they had attempted to measure ${ }^{13} \mathrm{C} /{ }^{12} \mathrm{C}$ with a tunable laser. Further discussions before the modern calibrations appeared at the conference in Trondheim in 1985 and are reported below.

Around 1960, data on the activity for surface and deep water of the different oceans were published (see e.g. Bien et al. 1963). The deep water of the Pacific Ocean, for example, was shown to have an apparent age about twice that of the Atlantic. For the Pacific, there was a pronounced latitude effect.

Stuiver and Suess (1966:535) discussed the relationship between ${ }^{14} \mathrm{C}$ ages and the true sample ages and wrote that cosmic rays, and thus the ${ }^{14} \mathrm{C}$ production, were dependent on the solar activity and the magnetic dipole moment. Another suggestion for possible variations was that uptake of carbon by roots of plants could lead to small differences, although probably negligible for trees during normal dating (see above). Suess (1968) also discussed the $\Delta^{14} \mathrm{C}$ dependence on the production. Increasing $\Delta^{14} \mathrm{C}$ corresponds to a quiet sun, while decreasing $\Delta^{14} \mathrm{C}$ corresponds to a large number of sunspots. 
From Suess' papers $(1968,1970 b)$, it is evident that he had great help from J C Houtermans in discussing the response of the atmospheric $\mathrm{CO}_{2}$ to the production rate of ${ }^{14} \mathrm{C}$.

Calibration curves, tables, and discussions were presented at Nobel Symposium 12 (e.g. Damon 1970; Damon et al. 1970; Michael and Ralph 1970; Ralph and Michael 1970; Suess 1970a,b). Suess' manner to draw his curve was discussed. He said he did that by "cosmic schwung" with many kinks and wiggles to demonstrate the "most probable character" of variations of the ${ }^{14} \mathrm{C}$ activity. Suess (1979a:541-3) stresses that the ${ }^{14} \mathrm{C}$ level may rise rapidly but go down slowly in the wiggles. He writes (1980:205) that ${ }^{14} \mathrm{C}$ rises by $1 \%$ in $~ 20$ yr and decreases by $1 \%$ in slightly more than twice that length of time. Suess (1979b) presents calibration data from measurements before August 1978. He also includes references to results from some well-performing laboratories (de Jong et al. 1979). An overview of the carbon cycle, chronologies, ${ }^{14} \mathrm{C}$ variations, and causes was given by Damon et al. (1978).

${ }^{13} \mathrm{C}$ together with ${ }^{14} \mathrm{C}$ in tree rings can be used for an estimate of the relationship between carbon from fossil fuel and that from biomass (Stuiver 1978a). ${ }^{13} \mathrm{C}$ in fossil fuel is about $-25 \%$ and that in the atmosphere about $-7 \%$, thus a difference of $18 \%$. ${ }^{13} \mathrm{C}$ for biomass is also about $-25 \%$, since the fraction in $\mathrm{C}_{4}$ plants is normally small and that for natural gas also small although the ${ }^{13} \mathrm{C}$ is more negative. The Suess effect was about $-2 \%$ in 1950 , although the documented carbon injection had been about $60 \times 10^{9}$ tons. The increase of the $\mathrm{CO}_{2}$, from 1850 until 1950, when the bombs still had a negligible effect on the ${ }^{14} \mathrm{C}$ level, was, however, about $10 \%$. A great deal of the injection was supposed to be stored in the vegetation or have gone to the sea. This was studied by Stuiver (1978a) by measurements on tree rings. He used a rather mild treatment and estimated the remaining amount of lignin to less than $1 \%$. This lignin is about $4 \%$ lighter in ${ }^{13} \mathrm{C}$ than cellulose. The overall reduction of ${ }^{13} \mathrm{C}$ was slightly more than $1 \%$. From the ${ }^{14} \mathrm{C}$ reduction, this was before the bomb, he could expect a ${ }^{13} \mathrm{C}$ reduction of about $2 \%$ of $18 \%$ until 1950 , or 0.36 . Extrapolated to 1970 , it will be $0.7 \%$. After removal of the industrial effect in his data, he saw that the main reduction in the atmosphere and biomass occurred between 1860 and 1930 and also amounted to $0.7 \%$. From this and extending the time range for the Suess effect to 1970, he found that about double the amount of biomass had gone to the sea than of fossil fuel. The documented injection of fossil fuel then yields an approximate figure of $120 \times 10^{9}$ tons for the net biomass release. Part has gone to the surface water and oceanic gyres and part to the bottom water by direct exchange with Arctic and Antarctic water. Every year, $0.5 \%$ goes this way. Using the box-diffusion model from 1975 , he finally concludes that the biomass injection has varied and that the same amount excess $\mathrm{CO}_{2}$ has gone to the sea, at 1950 , as stayed in the atmosphere.

${ }^{13} \mathrm{C} /{ }^{12} \mathrm{C}$ was also studied in Groningen (Tans and Mook 1980). An old question was whether any recycling could affect the ratio (Wickman 1952). If the $\mathrm{CO}_{2}$ is well mixed by wind, so the tree uses the free air, this should be a small effect. The authors are, however, concerned about the possible effect of temperature and precipitation, and that there is a ${ }^{13} \mathrm{C}$ and $\mathrm{CO}_{2}$ content variability of the assimilated $\mathrm{CO}_{2}$. The tree species were oak and beech, whereas Stuiver (1978a) used Douglas fir. The species used, when translocated resin with bomb activity and pretreated wood were discussed, varied: Cain and Suess (1976) and Cain (1979) used oaks; Long et al. (1979: Table 1) used bristlecone pine and cellulose from AD $1855-1875$, prepared from heartwood. They got a $\Delta^{14} \mathrm{C}$ value of $+2.29 \%$, which seems to indicate an unexpected enrichment (curves by Stuiver 1978b, 1982). Olsson (1980a) got a heartwood and a sapwood sample from the same bristlecone pine to study the pretreatment and a wood chemist investigated the extract in detail. It was also confirmed that the commonly used $\mathrm{NaOH}$ treatment to remove extract should be extended to last "overnight." The other species investigated in Uppsala were Pinus from Sweden and Fitzroya cupressoides from Argentina. 
Some extracts and all holocellulose samples were prepared by wood chemists at Mo and Domsjö $\mathrm{AB}$, Örnsköldsvik. A careful $\mathrm{NaOH}$ treatment was as successful as the holocellulose preparation. The wood chemists were, at the time for these studies and after discussions with other specialists, not prepared to draw conclusions about the metabolism. Olsson and Possnert (1992:761-2) observed that the SOL fraction from early wood was lower in activity than that from the late wood when the atmospheric activity was increasing because of the bomb, but that the opposite was true when the activity was decreasing. We also suggested a memory effect due to storage of nutrients in the roots. Tans and Mook (1980) found that whole wood and wood after AAA treatment gave the same $\delta^{13} \mathrm{C}$ values; that the values in a tree ring varied with the direction but followed the same pattern for the 2 fractions; AAA treatment and cellulose gave also the same pattern in different directions of a ring but differed by $\sim 1 \%$; that the values across the rings were not the same in the 2 opposite directions; that $\delta^{13} \mathrm{C}$ in samples in a fiber hardly differed from each other. The authors put forward the idea that some dissolved $\mathrm{CO}_{2}$ or $\mathrm{HCO}_{3}{ }^{-}$could be dislocated from the roots to the leaves.

The ${ }^{14} \mathrm{C}$ production was early related to the number of sunspots (see above). These are found near the solar equator, whereas solar wind is mainly located at the poles. The cosmic rays are deviated because of magnetic fields, the neutron production affected and thus also the ${ }^{14} \mathrm{C}$ production. The magnetic field strength of the solar wind should thus be a factor to consider. The ${ }^{14} \mathrm{C}$ content, as measured in tree rings, was also related to the exchange between the reservoirs. The re-evaluations (Stuiver and Quay 1980 and references therein) implied high-precision measurements. The production related to the sunspot number, $\mathrm{S}$, was given empirically in a linear equation with a negative term, $-0.00242 \mathrm{~S}$. Since the solar wind and the geomagnetic field interact, another linear equation was used with a term, Aa indices, reflecting the short-term random occurrence of magnetic activity superimposed on a long-term trend. The authors started from a 100-yr period and used the average Aa value to calculate a percentage change in the production in case of no solar wind (22.9\%). The value using the mean sunspot number during the same period and the earlier corresponding equation for production yields the value $7 \%$ for the variance of sunspots. The value of about $30 \%$ is more in accordance with measured variability. They used Douglas-fir tree samples. From the activity increase in older rings by resin because of bombs, they could estimate that the influence by "normal" activity variations was of no importance when using the chosen pretreatment in this investigation. As a byproduct, they even got good agreement between trees from Washington, Oregon, and Vancouver Island. They mainly used decadal samples. The record was translated to production rates. To do that, the authors chose the Oeschger diffusion model with essentially the same figures for the variables. They focused on the Maunder, Spörer, and Wolf minima with almost no sunspots. The auroral observations were also of interest here and, together with sunspots, provided some evidence for these minima. It is difficult to compare the present results, based on $860 \mathrm{yr}$ as recorded in rings until AD 1860, with earlier ones. The article by Lingenfelter and Ramaty (1970) covers, e.g. the time 1937 to 1967 with fossil fuels reducing the ${ }^{14} \mathrm{C}$ level. The authors instead chose their own calculations based on other results (see above), but extended in time. The uncertainties of neutron production and used values in the Oeschger model can, however, explain a discrepancy. The production changes when time goes toward the Maunder minimum (about AD 1645-1715). This was interpreted as some remaining solar wind from the polar regions, although with little interaction with Earth's magnetosphere. They also wrote that the time for change from high to low production during the Maunder minimum is different than that for the Spörer minimum (about AD 1416-1534). The authors consider the production rate to give information on solar wind conditions.

The ${ }^{14} \mathrm{C}$ timescale was checked by Stuiver (1978b) against other methods for some age ranges. For the latest 4 centuries, he claimed a precision better than $2 \%$. He used the normal, although rather 
simple, pretreatment for most of the samples and because of that he regarded the uncertainty to be less than $0.3 \%$. For samples older than from 1910, however, he used $\alpha$ cellulose. Many wiggles are apparent. The curves presented 4 yr later (Stuiver 1982) covers the AD time period, mostly decadal samples but also single-year tree-ring samples for 2 periods, although including a few points based on 2 or 3 yr. These sets do not indicate an amplitude beyond 12-yr precision for an 11-yr cycle. It is apparent that samples regarded as contemporaneous from different regions may yield different activities when determined in different laboratories. At that time, it was believed that it might be a bias effect except for the case with lower activity in the Southern Hemisphere. The agreement between Seattle and Belfast is excellent (p 18-9). Still, the differences must be explained. Stuiver also suggests possible variance in the respective laboratories. Stuiver (1982:18) gives evidence for bias for La Jolla against Seattle but also Seattle Sequoia against Seattle German oak. Such differences were reasons for studies of global variations and possibly corrections of the dendrodates. Still, 4 yr later (Stuiver and Becker 1986; Stuiver and Pearson 1986) presented their high-precision curves. These curves are not quite compatible since each sample can represent a single year up to 10 or even $20 \mathrm{yr}$. Internal replicate analyses reveal an error multiplier for Seattle of $\sim 1.5$ or 1.6 and for Belfast of $\sim 1.23$. That was the upper limit for the reproducibility (p 806). The values from the 2 laboratories can be used in the same diagrams since the offset is negligible.

At the Lower Hutt conference, Ralph and Michael (1973), using results in tabular form from Pennsylvania and Arizona, presented a table with the correction, without uncertainties, for samples older than $3500 \mathrm{BC}$ based on average deviations for 50 -yr periods (or 100-yr periods). That choice of long periods could cause problems since a change of $1 \mathrm{yr}$ (midpoint of uncorrected date) may cause a change of tens of years in the correction. The user also had to remember that the half-life 5730 was used. Later, Ralph et al. (1973) presented a new MASCA table with shorter periods. Meanwhile, Damon et al. (1973) based their diagrams on the same results plus results from Yale and presented their conversion table based on their own new Arizona results using the 2 half-lives 5730 and 5570. Their conversion table included also an uncertainty figure.

Many more calibration curves or tables were released. An elaborate table with diagrams was presented by Klein et al. (1982). It was constructed for $\sigma$ values of 20, 50, 100, 150, 200, and 300. It covers wood as old as $8000 \mathrm{yr}$. A table gives the systematic differences between the 5 laboratories: $\mathrm{A}, \mathrm{GrN}, \mathrm{Lj}, \mathrm{P}$, and Yale. La Jolla has the smallest uncertainty, but its value is lower than the mean and all the other 4 were higher. The next main step was the proceedings from Trondheim (Radiocarbon 28[2B]), published in 1986. Two calibration intervals were recommended (Stuiver and Pearson 1986; Pearson and Stuiver 1986). Stuiver et al. (1986a) presented some offsets results and also a discussion on Lake of the Clouds varves in the light of the revised Swedish varved clay chronology. Stuiver and Reimer (1986) presented a computer calibration program. Others were released in parallel with new and revised calibration curves.

When the dendrochronology was extended, the age range for well-known samples for calibration purposes could cover thousands of years. As an example, we can mention that Ferguson (1970) presented a Pinus aristata 7484-yr chronology at Nobel Symposium 12.

One calendar date corresponds to $1{ }^{14} \mathrm{C}$ date, but because of the wiggles, $1{ }^{14} \mathrm{C}$ date may correspond to more than 1 calendar date. It was recommended to use a calibration curve built on samples covering about the same number of years as the uncertainty of the sample covered (Mook 1983). A single sample may give a great ambiguity at the interpretation. If, for example, a log is dated, a series of samples may be selected and dated, each a few tree rings. The pattern of the varying ages compared with that for corresponding ages in a calibration curve with wiggles can yield a very good and 
reliable age. This was done in a very sophisticated manner by Beer et al. (1979) using statistical analysis and is called wiggle-matching.

The question of whether ${ }^{14} \mathrm{C}$ is produced in situ in wood affecting normal samples results has been on the agenda throughout all years. Radnell et al. (1979) wrote, after some experiments and theoretical discussions, that the possible effect is insignificant. Cain and Suess (1976) drew the same conclusion.

Some dates for calibration curves may have been in error apparently because of the ${ }^{13} \mathrm{C}$ normalization. Some $\Delta{ }^{14} \mathrm{C}$ peak values happen to coincide with extreme ${ }^{13} \mathrm{C}$ values in some early curve for which the used gas had been reburned to yield $\mathrm{CO}_{2}$ for the mass spectrometer. Suess (1979a:540) discarded results because of a memory effect. The pumping time between samples had been too short. (Note: For references in some papers by Suess, the printing year for papers given at Nobel Symposium 12 was given as 1971 instead of 1970.)

\section{Regional and Global Variations: Some Considerations Based on After-Bomb Measurements and Results on Tree Rings}

An indication that the injection from the stratosphere to the troposphere may occur at high latitudes and not only at mid-latitudes as recorded from radioactive fallout was seen by Olsson and Karlén (1965). The ${ }^{14} \mathrm{C}$ increase in the springs of $1962-3$ was $1 / 2$ to 1 month later at Kapp Linné, Spitsbergen, than that at Abisko $\left(78^{\circ} 04^{\prime} \mathrm{N}\right.$ and $68^{\circ} 20.5^{\prime} \mathrm{N}$, respectively). In 1962 , the activity for Abisko was lower than for Europe although the activity was much higher in 1960 and 1961 with a narrow peak especially in 1961. This is compatible with an injection rather far in the north with a relatively small area involved (Münnich and Vogel 1963 and references therein); results given by Östlund and Engstrand (1963:220) and Godwin and Willis (1964:136). A contamination could, however, not be completely excluded. These early samples were prepared in Uppsala but measured in Heidelberg. The activity values for Spitsbergen were as a mean almost $1 \%$, but mostly between 0 and 3\%, lower than those from Abisko as long as sampling went on, until 1992, for the conventional laboratory in Uppsala. The same tendency was seen later for the samples collected for the AMS laboratory in Uppsala. Additional atmospheric samples were collected on Iceland, Greenland, the Faroe Isles and Arctic islands, partly as gas and partly as plants (Olsson 1993b).

In an effort to correlate the ${ }^{14} \mathrm{C}$ concentration with the geomagnetism, Kigoshi and Hasegawa (1966) measured 27 samples from a trunk of cedar (Cryptomeria japonica). Three results were replicate measurements done at different occasions in the sequence, 24 were 20 -yr samples and 3 were 10 -yr samples. The detector was a 6.8 -L proportional counter filled to about $1 \mathrm{~atm}$ with acetylene. ${ }^{13} \mathrm{C}$ was measured on $\mathrm{SrCO}_{3}$ for 7 samples before the $\mathrm{SrO}_{2}$ preparation. If it was only the trend that should be determined, it was right as they did — to exclude the uncertainty of the standard measurements at the calculations of $\sigma$. They included the contribution from the voltage. Their $\Delta$ values, with $\sigma$ values in the range 2.8 to $3.6 \%$, are thus quite realistic, although the whole sequence could suffer from a bias at comparisons with other sequences. They plotted 14 results from the Arizona laboratory (Damon et al. 1963, 1964), also related to oxalic acid and ${ }^{13} \mathrm{C}$ normalized according to ${ }^{13} \mathrm{C}$ values on some of the samples. From the plot, it seemed obvious that the Japanese values are more negative than those from Arizona, by 0.5 to $1 \%$. Their explanation was that there was a difference in the air masses because of "a longer time of contact with the surface of the ocean." This effect was called "an island effect." The exchange between the troposphere and the mixed surface water varies on a global scale, so such an effect may be possible. The expression may be inadequate in this case, since we now can see from calibration tables based on decadal samples in the actual range (Stuiver et al. 1998), that the $\Delta$ values are in the range $11.5 \pm 1.2$ to $-25.3 \pm 1.2 \%$ instead of the Arizona values 
used, each with $\sigma$ values of $4-6 \%$ o. The Japanese values were between $-4.7 \pm 3.6$ and $-27.6 \pm 2.9 \%$. The age range here is limited to AD 100 to 1550 to exclude the period with the pronounced wiggles (Stuiver 1978b). Only 3 samples ( $\Delta=20 ; 9$ and 1 ) out of the 12 from Arizona remained. A revised comparison is needed before we can judge whether there is an activity deficiency or not for Yaku Island.

An activity difference between samples from Canada and Washington was explained by Damon et al. (1992) as releasing $\mathrm{CO}_{2}$, which had been trapped in frozen soil. Dörr and Münnich (1986) had written that such an outgassing was a realistic source for disturbing the natural level. The respiration from roots adds modern carbon, whereas the turnover by decomposition of old organic material contributes fossil carbon from the soil. In summer, the released gas is almost modern, but in winter it may exhibit some deficiency in ${ }^{14} \mathrm{C}$, but excess if the material decomposed is affected by bomb carbon. In case the decomposed material is found at some depth, it certainly is depleted and the turnover may be slow. Activity variations over the year will be a reality.

Starting in 1964, when performing pretreatment of the Argentine samples, we also intended to check the activity. We hesitated since we lacked a dendrochronology. The rings were checked, counted, and their width measured by a specialist, pending a possible dendrochronology for the area later on. The whole project was performed in collaboration with scientists in Bariloche, Groningen, and Uppsala. The collection in the field was part of an educational program in Uppsala. The project was initiated by de Waard in Groningen. The Dutch results (Lerman et al. 1970) yielded a deficiency of $4.5 \pm 1 \%$. The Uppsala results (10 values representing 6 ages BP [Olsson 1999b:101], given in a table, are from 600 to $660 \mathrm{BP}$ and indicate significantly a lower activity than those given by Stuiver and Becker (1993). Their 10 values are on 10-yr samples interlocated between 585 and 675 BP. Vogel et al. (1986, 1993) compared activity results from South Africa (1840-1890) with those from the Netherlands (1835-1900). The differences in these 2 papers were both about 5\%o with uncertainties approaching $1 \%$ o calculated on rather scattered values. Some of the values from the Netherlands are affected by the industrial effect. Among other examples given in the literature, it should be noted that it has been suggested that ENSO events have affected some results of some activity measurements.

\section{INTERLABORATORY COMPARISONS UNTIL EARLY 1980s AND CONSEQUENCES}

\section{Tree Rings}

The Glasgow laboratory invited 30 laboratories out of the 100 listed in Radiocarbon at the time, and 20 participated in an international comparison. Of these, 3 were classified as high-precision labs. The results were to be strictly anonymous (International Study Group 1982). Wood within 200-yr growth was supplied to be dated as eight 10 -yr samples. These should be pretreated by the participants, to yield cellulose according to a recipe. The chemical treatment proved to differ between the participants, but special tests in 2 of the laboratories showed that this was not critical for the actual rings. The spread of the results was greater than the quoted errors would imply. Besides bias, removed or not removed and mostly positive for gas counters as a group and negative for liquid scintillation counters, the quoted errors had to be increased to quantify the observed variability. The multiplication factor, in later comparisons often called $K$, was $\leq 1$ for the 3 laboratories quoting errors $\geq 80$ yr. From a statistical point of view, it seems quite realistic to find some laboratories with $K$ values $\leq 1$ especially since the given values, for ages and errors, were calculated and rounded according to Stuiver and Polach $(1977: 357,362)$. The final calculated values depended on what values the other laboratories gave. Instead of concluding that this is due to overestimates of errors, one should conclude that it is possible to reach values $\leq 1$. All uncertainties, in the measurements, should 
be estimated before the final uncertainty is given to avoid underestimated systematical spread (bias) between the laboratories. Examples are given above.

The international comparisons have revealed that the uncertainties given by most laboratories on age determinations are underestimated. It is not enough to include only the statistics from the number of decays. A thorough effort was taken by Olsson et al. (1962) and repeated by Olsson (1988: 189) to declare all possible statistical uncertainties and systematical contributions to the final result. Otlet (1979) discussed how the uncertainties for scintillation counters should be treated. Pearson (1979) listed the errors as those deriving from statistics of counting; those associated with uncertainty after proper corrections, those deriving from uncertainty of the reproducibility and the assumption that the vial efficiency and background are constant. Pearson's results rendered his scintillator measurements as outstanding in quality. Similarly, Tans and Mook (1979) analyzed the uncertainties for the Groningen gas counters. Stuiver's high-precision laboratory also added much to the calibration.

Instead of the early practice of using a few results in the calculations for background and standard, measured before and after a sample, it is now regarded possible and necessary to use long periods to be able to find proper figures for all possible corrections. For example, long-term drift in efficiency can be revealed. Memory effects have also been detected. These can be due to too short evacuating of the detectors between the samples. It was recommended to care about the sequence for measuring the samples to eliminate that risk.

\section{DATE LISTS, DATABASES, AND FORMS}

In 1972 in Lower Hutt, the date lists were discussed. Many of the participants were of the opinion that the publishing procedure was time consuming. In fact, I myself published my latest conventional Uppsala list, XII, in 1978. The next one was never finished-partly since I felt I hadn't enough pertinent information on my forms to be submitted together with the samples, in spite of that the submitters were asked to fill out my forms. Many laboratories had exchanged forms and improved their own throughout the years. The forms are also useful when planning the pretreatment and succession at the measurements to avoid possible memory effects and to discuss whether it was meaningful to date the actual samples. A process to standardize the forms based on responses on a survey started. Many of the laboratories were contacted. Naturally, the heads of the laboratories had too many opinions about what was needed or wanted to get on such forms. It was suggested, for example, that a full account should be provided by the submitter as well as pertinent information such as photographs or particular observations. Some space was allocated for the dater. Many of the submitters of samples would probably think that it was too much information to give in advance and that they wanted to keep it to themselves until they were ready to publish and discuss it. Other users of dates may prefer more information. We must also remember that some laboratories are run commercially or more or less on a service basis and others in collaboration with the submitters.

At Nobel Symposium 12, an archaeologist discussed a summary of uncertainties of ${ }^{14} \mathrm{C}$ dating (Neustupný 1970:24-29) and asked for greater accuracy. The aim for this symposium was partly to scrutinize Egyptian samples used for ${ }^{14} \mathrm{C}$ dating concerning the background and reliability (SäveSöderbergh and Olsson 1970). The Pharaonic chronology was outlined as well as the astronomical dating. Results from different laboratories and on different material, taken as given in the literature, show good statistics in some cases but not in all. Säve-Söderbergh finds the dates for the Pharaonic

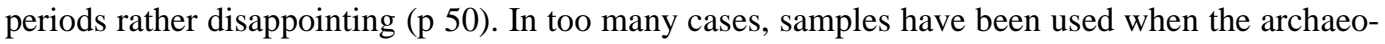
logical age is not well determined ( $p$ 47). A general statement was that "one isolated sample or laboratory dating is of little value." 


\section{ACKNOWLEDGMENTS}

This study is based on experiences during half a century starting in September 1955. I am thankful for the support given by Uppsala University and for the funding by the Swedish Natural Science Research Council of most of the expenses. Special thanks are due to the present board and the head of the Department for allowing an office space to enable me to compile this essay.

\section{REFERENCES}

Andersen EB. 1936. Eine empfindliche Zählrohranordnung. Zeitschrift für Physik 98:597-604. In German.

Anderson EC, Libby WF. 1951. World-wide distribution of natural radiocarbon. The Physical Review 81:64-9.

Bada JL, Vrolijk CD, Brown S, Druffel ERM, Hedges REM. 1987. Bomb radiocarbon in metabolically inert tissues from terrestrial and marine mammals. Geophysical Research Letters 14(10):1065-7.

Bannister B, Damon PE. 1973. A dendrochronologically-derived primary standard for radiocarbon dating. In: Proceedings of the Eighth International Radiocarbon Dating Conference. Lower Hutt, New Zealand, 18-25 October 1972. p 676-85.

Barker H, Mackey CJ. 1959. British Museum natural radiocarbon measurements I. American Journal of Sciences Radiocarbon Supplement 1:81-6.

Bartlett HH. 1951. Radiocarbon datability of peat, marl, caliche, and archaeological materials. Science 114(2951):55-6.

Baxter MS, Walton A. 1970. Glasgow University radiocarbon measurements III. Radiocarbon 12(2):496502 .

Baxter MS, Ergin M, Walton A. 1969. Glasgow University radiocarbon measurements I. Radiocarbon 11(1): 43-52.

Beer J, Giertz V, Möll M, Oeschger H, Riesen T, Strahm C. 1979. The contribution of the Swiss lake-dwellings to the calibration of radiocarbon dates. In: Berger R, Suess HE, editors. Radiocarbon Dating. Proceedings of the Ninth International Conference. Los Angeles and La Jolla 1976. University of California Press. p 566-84.

Bella F, Alessio M, Fratelli P. 1968. A determination of the half-life of ${ }^{14}$ C. Il Nuovo Cimento B 58(1):232-46.

Bender MM. 1968. Mass spectrometric studies of carbon 13 variations in corn and other grasses. Radiocarbon 10(2):468-72.

Bergquist NO. 1964. Absorption of carbon dioxide by plant roots. Botaniska notiser 117(Fasc.3):249-61.

Bien GS, Rakestraw NW, Suess HE. 1963. Radiocarbon dating of the deep water of the Pacific and Indian oceans. In: Radioactive Dating. Vienna: IAEA. p 159_ 73.

Birkenmajer K, Olsson IU. 1971. Radiocarbon dating of raised marine terraces at Hornsund, Spitsbergen, and the problem of land uplift. Norsk Polarinstitutt Årbok 1969:17-43.

Birkenmajer K, Olsson IU. 1998. Radiocarbon dating of whale bones from the 17 th century whaling sites at Gåshamna, Hornsund, south Spitsbergen. Bulletin of the Polish Academy of Sciences 46(2):109-32.

Bolin B. 1960. On the exchange of carbon dioxide between the atmosphere and the sea. Tellus 12:274-81.

Brenninkmeijer CAM, Mook WG. 1979. The effect of electronegative impurities on $\mathrm{CO}_{2}$ proportional counting: an on-line purity test counter. In: Berger R, Suess HE, editors. Radiocarbon Dating. Proceedings of the Ninth International Conference. Los Angeles and La Jolla 1976. University of California Press. p 185-96.

Broecker WS, Olson EA. 1959. Lamont radiocarbon measurements VI. American Journal of Science Radiocarbon Supplement 1:111-32.

Broecker WS, Olson EA. 1960. Radiocarbon from nuclear tests, II. Science 132(3429):712-21.

Broecker WS, Olson EA. 1961. Lamont radiocarbon measurements VIII. Radiocarbon 3:176-204.

Broecker WS, Schulert A, Olson EA. 1959. Bomb carbon-14 in human beings. Science 130(3371):331-2.

Brown TA, Nelson DE, Vogel JS, Southon JR. 1988. Improved collagen extraction by modified Longin method. Radiocarbon 30(2):171-7.

Bruns M, Levin I, Münnich KO, Hubberten HW, Fillipakis S. 1980. Regional sources of volcanic carbon dioxide and their influence on ${ }^{14} \mathrm{C}$ content of present-day plant material. Radiocarbon 22(2):532-6.

Bumsted MP. 1984. Human variation: $\delta^{13} \mathrm{C}$ in adult bone collagen and the relation to diet in an isochronous $\mathrm{C}_{4}$ (maize) archaeological population [PhD dissertation]. Los Alamos-10259-T. 188 p.

Burleigh R. 1973. Bomb combustion of radiocarbon samples. In: Proceedings of the Eighth International Radiocarbon Dating Conference. Lower Hutt, New Zealand, 18-25 October 1972. p 110-9.

Burleigh R, Matthews K, Leese M. 1984. Consensus $\delta^{13} \mathrm{C}$ values. Radiocarbon 26(1):46-53.

Cadogan G. 1988. Dating of the Santorini eruption (reply). Nature 332(6163):401.

Cain WF. 1979. ${ }^{14} \mathrm{C}$ in modern American trees. In: Berger R, Suess HE, editors. Radiocarbon Dating. Proceedings of the Ninth International Conference. Los Angeles and La Jolla 1976. University of California Press. p 495-510.

Cain WF, Suess HE. 1976. Carbon 14 in tree rings. Journal of Geophysical Research 81(21):3688-94.

Calder JA, Parker PL. 1973. Geochemical implications of induced changes in $\mathrm{C}^{13}$ fractionation by blue-green 
algae. Geochimica et Cosmochimica Acta 37:133-40.

Calf GE. 1978. A procedure for the preparation of benzene from ${ }^{14} \mathrm{C}$ NBS oxalic acid standard. Radiocarbon 20(2):169-70.

Callow WJ, Baker MJ, Hassal GI. 1965. National Physical Laboratory radiocarbon measurements III. Radiocarbon 7:156-61.

Cato I. 1985. The definite connection of the Swedish geochronological time scale with the present, and the new date of the zero year in Döviken, northern Sweden. Boreas 14:117-22.

Cavallo LM, Mann WB. 1980. New National Bureau of Standards contemporary carbon-14 standards. Radiocarbon 22(3):962-3.

Chatters RM, Crosby III JW, Engstrand LG. 1969. Fumarole gaseous emanations: their influence on carbon-14 dates. In: Washington State University Technical Extension Service. Circular 32

Craig H. 1953. The geochemistry of the stable carbon isotopes. Geochimica et Cosmochimica Acta 3:53-92.

Craig H. 1954. Carbon 13 in plants and the relationships between carbon 13 and carbon 14 variations in nature. Journal of Geology 62(2):115-49.

Craig H. 1961. Mass-spectrometer analyses of radiocarbon standards. Radiocarbon 3:1-3.

Currie LA, Polach HA. 1980. Exploratory analysis of the international radiocarbon cross-calibration data: consensus values and interlaboratory error. Preliminary note. Radiocarbon 22(3):933-5.

Damon PE. 1970. Climatic versus magnetic perturbation of the atmospheric $\mathrm{C} 14$ reservoir. In: Olsson IU, editor. Radiocarbon Variations and Absolute Chronology. Nobel Symposium 12, Uppsala, 11-15 August 1969. Stockholm: Almqvist \& Wiksell; New York: John Wiley \& Sons. p 571-93.

Damon PE, Long A, Sigalove JJ. 1963. Arizona radiocarbon dates IV. Radiocarbon 5:283-301.

Damon PE, Haynes CV, Long A. 1964. Arizona radiocarbon dates V. Radiocarbon 6:91-107.

Damon PE, Long A, Grey DC. 1970. Arizona radiocarbon dates for dendrochronologically dated samples. In: Olsson IU, editor. Radiocarbon Variations and $A b-$ solute Chronology. Nobel Symposium 12, Uppsala 11-15 August 1969. Stockholm: Almqvist \& Wiksell; New York: John Wiley \& Sons. p 615-8.

Damon PE, Long A, Wallick EI. 1973. Dendrochronologic calibration of the carbon-14 time scale. In: Proceedings of the Eighth International Radiocarbon Dating Conference. Lower Hutt, New Zealand, 18-25 October 1972. p 44-59.

Damon PE, Lerman JC, Long A. 1978. Temporal fluctuations of atmospheric ${ }^{14} \mathrm{C}$ : causal factors and implications. Annual Review of Earth and Planetary Sciences 6:457-94.

Damon PE, Burr G, Cain WJ, Donahue DJ. 1992. Anomalous 11 -year $\Delta{ }^{14} \mathrm{C}$ cycle at high latitudes? Radiocarbon 34(2):235-8.

Dansgaard W, Johnsen SJ, Clausen HB, Langway Jr CC.
1970. Ice cores and paleoclimatology. In: Olsson IU, editor. Radiocarbon Variations and Absolute Chronology. Nobel Symposium 12, Uppsala, 11-15 August 1969. Stockholm: Almqvist \& Wiksell; New York: John Wiley \& Sons. p 337-51.

Dauchot-Dehon M, Heylen J. 1979. Institut Royal du Patrimoine Artistique radiocarbon dates VI. Radiocarbon 21(2):180-5.

Deevey Jr ES, Gross MS, Hutchinson GE, Kraybill HL. 1954. The natural $\mathrm{C}^{14}$ contents of materials from hardwater lakes. Proceedings of the National Academy of Sciences of the USA 40(5):285-8.

Deines P. 1980. The isotopic composition of reduced organic carbon. In: Fritz P, Fontes JCh, editors. Handbook of Environmental Isotope Geochemistry. Volume 1. Amsterdam: Elsevier. p 329-406.

de Jong AFM, Mook WG, Becker B. 1979. Confirmation of the Suess wiggles: 3200-3700 BC. Nature 280(5717):48-9.

de Vries H. 1956a. Purification of $\mathrm{CO}_{2}$ for use in a proportional counter for ${ }^{14} \mathrm{C}$ age measurements. Applied Scientific Research B 5:387-400.

de Vries H. 1956b. The contribution of neutrons to the background of counters used for ${ }^{14} \mathrm{C}$ age measurements. Nuclear Physics 1:477-9.

de Vries H. 1957. The removal of radon from $\mathrm{CO}_{2}$ for use in ${ }^{14} \mathrm{C}$ age measurements. Applied Scientific Research $B$ 6:461-70.

de Vries H. 1958. Variation in concentration of radiocarbon with time and location on Earth. Proceedings Koninklijke Nederlandse Akademie van Wetenschappen Series B 61(2):94-102.

de Vries H, Barendsen GW. 1953. Radiocarbon dating by a proportional counter filled with carbon dioxide. Physica 19:987-1003.

de Vries H, Barendsen GW. 1954. Measurements of age by the carbon-14 technique. Nature 174(4442):113841.

de Vries H, Waterbolk HT. 1958. Groningen radiocarbon dates III. Science 128:1550-6.

de Vries AE, Haring A, Slots W. 1956. Separation of ${ }^{14} \mathrm{C} /$ ${ }^{16} \mathrm{O}$ and ${ }^{12} \mathrm{C}-{ }^{18} \mathrm{O}$ by thermal diffusion. Physica 22 : 247-8.

Donner JJ, Jungner H. 1980. Radiocarbon ages of shells in Holocene marine deposits. Radiocarbon 22(2): 556-61.

Donner JJ, Jungner H, Vasari Y. 1971. The hard-water effect on radiocarbon measurements of samples from Säynäjälampi, north-east Finland. Commentationes Physico-Mathematicae 41:307-10.

Dörr H, Münnich KO. 1986. Annual variations of the ${ }^{14} \mathrm{C}$ content of soil $\mathrm{CO}_{2}$. Radiocarbon 28(2A):338-45.

Dresser Q. 1985. University College Cardiff radiocarbon dates I. Radiocarbon 27(2B):338-85.

Druffel EM, Mok HYI. 1983. Time history of human gallstones: application of the post-bomb radiocarbon signal. Radiocarbon 25(2):629-36.

Editorial. 1972. Antiquity 46(184):265. 
El-Daoushy MFAF, Olsson IU, Oro FH. 1978. The EDTA and $\mathrm{HCl}$ methods of pre-treating bones. Geologiska Föreningens i Stockholm Förhandlingar 100: 213-9.

Erlenkeuser H. 1979. A thermal diffusion plant for radiocarbon isotope enrichment from natural samples. In: Berger R, Suess HE, editors. Radiocarbon Dating. Proceedings of the Ninth International Conference. Los Angeles and La Jolla 1976. University of California Press. p 216-37.

Evin J, Marechal J, Marien G. 1983. Lyon natural radiocarbon measurements IX. Radiocarbon 25(1):59-128.

Ferguson CW. 1970. Dendrochronology of bristlecone pine, Pinus aristata. Establishment of a 7484-year chronology in the White Mountains of eastern-central California, U.S.A. In: Olsson IU, editor. Radiocarbon Variations and Absolute Chronology. Nobel Symposium 12, Uppsala, 11-15 August 1969. Stockholm: Almqvist \& Wiksell; New York: John Wiley \& Sons. p 237-59.

Feyling-Hanssen RW, Olsson I. 1959-60. Five radiocarbon datings of Post Glacial shorelines in Central Spitsbergen. Norsk Geografisk Tidsskrift 17(1-4):122-31.

Folk RL, Valastro Jr S. 1979. Dating of lime mortar by ${ }^{14} \mathrm{C}$. In: Berger R, Suess HE, editors. Radiocarbon Dating. Proceedings of the Ninth International Conference. Los Angeles and La Jolla 1976. University of California Press. p 721-32.

Freundlich JC, Kuper R, Breunig P, Bertram H-G. 1989. Radiocarbon dating of ostrich eggshells. Radiocarbon 31(3):1030-4.

Fromm E. 1970. An estimation of errors in the Swedish varve chronology. In: Olsson IU, editor. Radiocarbon Variations and Absolute Chronology. Nobel Symposium 12, Uppsala, 11-15 August 1969. Stockholm: Almqvist \& Wiksell; New York: John Wiley \& Sons. p 163-72.

Geyh MA. 1967. Experience gathered in the construction of low-level counters. In: Radioactive Dating and Methods of Low-Level Counting. Vienna: IAEA. p 575-91.

Geyh MA. 1973. A comparison: proportional counter and liquid scintillation spectrometer for radiocarbon dating. In: Proceedings of the Eighth International Radiocarbon Dating Conference. Lower Hutt, New Zealand, 18-25 October 1972. p 189-201.

Geyh MA. 1979. ${ }^{14} \mathrm{C}$ routine dating of marine sediments. In: Berger R, Suess HE, editors. Radiocarbon Dating. Proceedings of the Ninth International Conference. Los Angeles and La Jolla 1976. University of California Press. p 480-91.

Geyh MA, Merkt J, Müller H. 1970. ${ }^{14}$ C-Datierung limnischer Sedimente und die Eichung der ${ }^{14} \mathrm{C}$-Zeitskala. Naturwissenschaften 57:564-7. In German.

Geyh MA, Merkt J, Müller H. 1971. Sediment-, Pollen-, und Isotopenanalysen an jahreszeitlich geschichteten Ablagerungen im zentralen Teil des Schleinsees. Ar- chiv Hydrobiologie 69:366-99. In German.

Geyh MA, Krumbein WE, Kudrass H-R. 1974. Unreliable ${ }^{14} \mathrm{C}$ dating of long-stored deep-sea sediments due to bacterial activity. Marine Geology 17:M45-50.

Gillespie R, Hedges REM. 1983. Sample chemistry for the Oxford High Energy Mass Spectrometer. Radiocarbon 25(2):771-4.

Glad T, Nydal R. 1982. Radial transport of ${ }^{14} \mathrm{C}$ in Norwegian pine. In: Proceedings of the Second Nordic Conference on the Application of Scientific Methods in Archaeology. PACT 7(1):45-52.

Godwin H. 1951. Comments on radiocarbon dating for samples from the British Isles. American Journal of Science 249:301-7.

Godwin H. 1969. The value of plant materials for radiocarbon dating. American Journal of Botany 56(7): 723-31.

Godwin H, Willis EH. 1964. Cambridge University natural radiocarbon measurements VI. Radiocarbon 6: 116-37.

Grey DC, Damon PE, Haynes CV, Long A. 1969. Carbon-isotope fractionation during wet oxidation of oxalic acid. Radiocarbon 11(1):1-2.

Grootes PM. 1977. Thermal diffusion isotopic enrichment and radiocarbon dating beyond 50,000 years BP [PhD dissertation]. University of Groningen, the Netherlands. $221 \mathrm{p}$.

Grootes PM, Stuiver M. 1979. The Quaternary Isotope Laboratory thermal diffusion enrichment system: description and performance. Radiocarbon 21(2):13964.

Grootes PM, Mook WG, Vogel JC, de Vries AE, Haring A, Kistemaker J. 1975. Enrichment of radiocarbon for dating samples up to 75,000 years. Zeitschrift für Naturforschung 30a:1-14.

Gulliksen S, Nydal R. 1979. Further improvement of counter background and shielding. In: Berger R, Suess HE, editors. Radiocarbon Dating. Proceedings of the Ninth International Conference. Los Angeles and La Jolla 1976. University of California Press. p 176-84.

Gurfinkel DM. 1987. Comparative study of the radiocarbon dating of different bone collagen preparations. Radiocarbon 29(1):45-52.

Håkansson S. 1979. Radiocarbon activity in submerged plants from various south Swedish lakes. In Berger R, Suess HE, editors. Radiocarbon Dating. Proceedings of the Ninth International Conference. Los Angeles and La Jolla 1976. University of California Press. p 433-43.

Hammer CU, Clausen HB, Dansgaard W. 1980. Greenland ice sheet evidence of post-glacial volcanism and its climatic impact. Nature 288(5788):230-5.

Hammer CU, Clausen HB, Tauber H. 1986. Ice-core dating of the Pleistocene/Holocene boundary applied to a calibration of the ${ }^{14} \mathrm{C}$ time scale. Radiocarbon $28(2 \mathrm{~A})$ : 284-91.

Hammer CU, Clausen HB, Friedrich WL, Tauber H. 
1987. The Minoan eruption of Santorini in Greece dated to 1645 BC? Nature 328(6130):517-9.

Hammer CU, Clausen HB, Friedrich WL, Tauber H. 1988. Dating of the Santorini eruption (reply). Nature 332(6163):401.

Harkness DD, Walton A. 1972. Further investigations of the transfer of bomb ${ }^{14} \mathrm{C}$ to man. Nature $240(5379)$ : 302-3.

Haynes Jr CV. 1966. Radiocarbon samples: chemical removal of plant contaminants. Science 151(3716): $1391-2$.

Haynes Jr CV, Damon PE, Grey DC. 1966. Arizona radiocarbon dates VI. Radiocarbon 8:1-21.

Heier-Nielsen S, Heinemeier J, Nielsen HL, Rud N. 1995. Recent reservoir ages for Danish fjords and marine waters. Radiocarbon 37(3):875-82.

Heikkinen A, Äikää O. 1977. Geological Survey of Finland radiocarbon measurements VII. Radiocarbon 19(2):263-79.

Heikkinen A, Koivisto A-K, Aikää O. 1974. Geological Survey of Finland radiocarbon measurements VI. Radiocarbon 16(2):252-68.

Hörnsten $\AA$, Olsson IU. 1964. En $C^{14}$-datering av glaciallera från Lugnvik, Ångermanland. Geologiska Föreningens i Stockholm Förhandlingar 86:206-10.

Hughes MK. 1988. Ice-layer dating of eruption at Santorini. Nature 335(6187):211-2.

International Study Group. 1982. An inter-laboratory comparison of radiocarbon measurements in tree rings. Nature 298(5875):619-23.

Johnson F. 1959. A bibliography of radiocarbon dating. American Journal of Science Radiocarbon Supplement 1:199-214.

Kigoshi K, Hasegawa H. 1966. Secular variation of atmospheric radiocarbon concentration and its dependence on geomagnetism. Journal of Geophysical Re search 71(4):1065-71.

Kim SM. 1970. Wet oxidation of oxalic acid used in radiocarbon dating and ${ }^{14} \mathrm{C}$ fractionation during the oxidation. Doehan Hwahak Hwejee (Journal of the Korean Chemical Society) 14(1):49-50.

Klein J, Lerman JC, Damon PE, Ralph EK. 1982. Calibration of radiocarbon dates: tables based on the consensus data of the workshop on calibrating the radiocarbon time scale. Radiocarbon 24(2):103-50.

Kuc T. 1986. Carbon isotopes in atmospheric $\mathrm{CO}_{2}$ of the Kraków region: a two-year record. Radiocarbon 28(2A):649-54.

Kuc T. $1987 .{ }^{14} \mathrm{C}$ traced in Kraków after the Chernobyl accident. Radiocarbon 29(3):319-22.

LaMarche Jr VC, Hirschboeck KK. 1984. Frost rings in trees as records of major volcanic eruptions. Nature 307(5947):121-6.

Leavitt SW, Long A. 1982. Evidence for ${ }^{13} \mathrm{C} /{ }^{12} \mathrm{C}$ fractionation between tree leaves and wood. Nature 298(5876):742-4.

Lerman JC. 1973. Carbon 14 dating: origin and correction of isotope fractionation errors in terrestrial living matter. In: Proceedings of the Eighth International Radiocarbon Dating Conference. Lower Hutt, New Zealand, 18-25 October 1972. p 612-24.

Lerman JC, Mook WG, Vogel JC. 1970. C14 in tree rings from different localities. In: Olsson IU, editor. Radiocarbon Variations and Absolute Chronology. Nobel Symposium 12, Uppsala, 11-15 August 1969. Stockholm: Almqvist \& Wiksell; New York: John Wiley \& Sons. p 275-301.

Levi H. 1955. Bibliography of radiocarbon dating. Quaternaria 2:257-63.

Levi H. 1957. Bibliography of radiocarbon dating. Quaternaria 4:205-10.

Levin I, Münnich KO, Weiss W. 1980. The effect of anthropogenic $\mathrm{CO}_{2}$ and ${ }^{14} \mathrm{C}$ sources on the distribution of ${ }^{14} \mathrm{C}$ in the atmosphere. Radiocarbon 22(2):379-91.

Libby WF. 1955. Radiocarbon Dating. 2nd edition. Chicago: University of Chicago Press. 175 p.

Libby WF. 1970. Ruminations on radiocarbon dating. In: Olsson IU, editor. Radiocarbon Variations and Absolute Chronology. Nobel Symposium 12, Uppsala, 1115 August 1969. Stockholm: Almqvist \& Wiksell; New York: John Wiley \& Sons. p 629-40.

Libby LM, Libby WF. 1973. Vulcanism and radiocarbon dates. In: Proceedings of the Eighth International Radiocarbon Dating Conference. Lower Hutt, New Zealand, 18-25 October 1972. p 86-9.

Lingenfelter RE, Ramaty R. 1970. Astrophysical and geophysical variations in $\mathrm{C} 14$ production. In: Olsson $\mathrm{IU}$, editor. Radiocarbon Variations and Absolute Chronology. Nobel Symposium 12, Uppsala, 11-15 August 1969. Stockholm: Almqvist \& Wiksell; New York: John Wiley \& Sons. p 513-37.

Long A, Arnold LD, Damon PE, Ferguson CW, Lerman JC, Wilson AT. 1979. Radial translocation of carbon in Bristlecone pine. In: Berger R, Suess HE, editors. Radiocarbon Dating. Proceedings of the Ninth International Conference. Los Angeles and La Jolla 1976. University of California Press. p 532-7.

Long A, Hendershott RB, Martin PS. 1983. Radiocarbon dating of fossil eggshell. Radiocarbon 25(2):533-40.

Longin R. 1971. New method of collagen extraction for radiocarbon dating. Nature 230(5291):241-2.

Lowdon JA. 1969. Isotope fractionation in corn. Radiocarbon 11(2):391-3.

Lowdon JA. 1970. Carbon-isotope fractionation during dry combustion of oxalic acid. Radiocarbon 12(2): 347-9.

Lyon TDB, Baxter MS. 1978. Stable carbon isotopes in human tissues. Nature 273(5665):750-1.

Mangerud J, Gulliksen S. 1975. Apparent radiocarbon ages of recent marine shells from Norway, Spitsbergen, and Arctic Canada. Quaternary Research 5:26373.

Mann WB. 1983. An international reference material for radiocarbon dating. Radiocarbon 25(2):519-27.

Mann WB, Marlow WF, Hughes EE. 1961. The half-life of carbon-14. International Journal of Applied Radi- 
ation and Isotopes 11(1):57-67.

Manning SW. 1988. Dating of the Santorini eruption. Nature 332(6163):401.

McCartney M, Baxter MS, McKay K, Scott EM. 1986. Global and local effects of ${ }^{14} \mathrm{C}$ discharges from the nuclear fuel cycle. Radiocarbon 28(2A):634-43.

Michael HN, Ralph EK. 1970. Correction factors applied to Egyptian radiocarbon dates from the era before Christ. In: Olsson IU, editor. Radiocarbon Variations and Absolute Chronology. Nobel Symposium 12, Uppsala, 11-15 August 1969. Stockholm: Almqvist \& Wiksell; New York: John Wiley \& Sons. p 109-20.

Michael HN, Ralph EK. 1973. Discussion of radiocarbon dates obtained from precisely dated Sequoia and Bristlecone pine samples. In: Proceedings of the Eighth International Radiocarbon Dating Conference. Lower Hutt, New Zealand, 18-25 October 1972. p 27-43.

Mook WG. $1983 .{ }^{14} \mathrm{C}$ calibration curves depending on sample time-width. In: Hackens T, Mook WG, Waterbolk HT, editors. Proceedings of ${ }^{14} \mathrm{C}$ and Archaeology, Groningen, the Netherlands 1981. PACT 8:517-25.

Münnich KO. 1957. Heidelberg natural radiocarbon measurements I. Science 126(3266):194-9.

Münnich KO, Vogel JC. 1963. Investigation of meridional transport in the troposphere by means of carbon14 measurements. In: Radioactive Dating. Vienna: IAEA. p 189-97.

Nehmi VA. 1980. Isotopic fractionation of NBS oxalic ${ }^{14} \mathrm{C}$ standard and its effect on calculated age of materials. Radiocarbon 22(2):501-4.

Neustupný E. 1970. The accuracy of radiocarbon dating. In: Olsson IU, editor. Radiocarbon Variations and $A b-$ solute Chronology. Nobel Symposium 12, Uppsala 11-15 August 1969. Stockholm: Almqvist \& Wiksell; New York: John Wiley \& Sons. p 23-34.

Noakes JE, Kim SM, Stipp JJ. 1966. Chemical and counting advances in liquid scintillation age dating. In: Chatters RM, editor. Proceedings of the Sixth International Conference Radiocarbon and Tritium Dating. Pullman, Washington, 7-11 June 1965 (Conf. 650652). p 68-92.

Nydal R. 1959. Trondheim natural radiocarbon measurements I. American Journal of Science Radiocarbon Supplement 1:76-80.

Nydal R, Lövseth K. 1983. Tracing bomb ${ }^{14} \mathrm{C}$ in the atmosphere 1962-1980. Journal of Geophysical Research 88(C6):3621-42.

Nydal R, Lövseth K, Syrstad O. 1971. Bomb ${ }^{14} \mathrm{C}$ in the human population. Nature 232(5310):418-21.

Oana S, Deevey ES. 1960. Carbon 13 in lake waters, and its possible bearing on paleolimnology. American Journal of Science, Bradley Volume 258A:253-72.

Oeschger H, Siegenthaler U. 1979. Prognosis for the expected $\mathrm{CO}_{2}$ increase due to fossil fuel combustion. In: Berger R, Suess HE, editors. Radiocarbon Dating. Proceedings of the Ninth International Conference. Los Angeles and La Jolla 1976. University of Califor- nia Press. p 633-42.

Oeschger H, Siegenthaler U, Schotterer U, Gugelman A. 1975. A box diffusion model to study the carbon dioxide exchange in nature. Tellus 27:168-92.

Oeschger H, Lehmann B, Loosli HH, Moell M, Neftel A, Schotterer U, Zumbrunn R. 1979. Recent progress in low level counting and other isotope detection methods. In: Berger R, Suess HE, editors. Radiocarbon Dating. Proceedings of the Ninth International Conference. Los Angeles and La Jolla 1976. University of California Press. p 147-57.

Oeschger H, Beer J, Loosli HH, Schotterer U. 1981. Low-level counting systems in deep underground laboratories. In: Methods of Low-Level Counting and Spectrometry. Vienna: IAEA. p 459-74.

Olson EA, Broecker WS. 1959. Lamont natural radiocarbon measurements V. American Journal of Science Radiocarbon Supplement 1:1-28.

Olsson I. 1959. Uppsala natural radiocarbon measurements I. American Journal of Science Radiocarbon Supplement 1:87-102.

Olsson I. 1960. Uppsala natural radiocarbon measurements II. American Journal of Science Radiocarbon Supplement 2:112-28.

Olsson IU. 1968. Radiocarbon analyses of lake sediment samples from Bjørnøya. Appendix in: Hyvärinen $\mathrm{H}$. Late-Quaternary sediment cores from Bjørnøya. Geografiska Annaler 50A:246-7.

Olsson IU, editor. 1970. Radiocarbon Variations and Absolute Chronology. Nobel Symposium 12, Uppsala, 11-15 August 1969. Stockholm: Almqvist \& Wiksell; New York: John Wiley \& Sons.

Olsson IU. 1972a. The pretreatment of samples and the interpretation of the results of ${ }^{14} \mathrm{C}$ determinations. Acta Universitatis Oulensis Ser A3, Geologica 1:9_ 37.

Olsson IU. 1972b. The $\mathrm{C}^{14}$ dating of samples for botanical studies of prehistoric agriculture in northern Ångermanland. Early Norrland 1:35-41.

Olsson IU. 1973. The radiocarbon dating of Ivory Coast shell mounds. West African Journal of Archaeology 3: 215-20.

Olsson IU. 1977. Något om val av $\mathrm{C}^{14}$-prov och val av presentationssätt av resultaten. Fornvännen 72:20812. In Swedish, summary in English.

Olsson IU. 1979a. The importance of the pretreatment of wood and charcoal samples. In: Berger R, Suess HE, editors. Radiocarbon Dating. Proceedings of the Ninth International Conference. Los Angeles and La Jolla 1976. University of California Press. p 135-46.

Olsson IU. 1979b. The radiocarbon contents of various reservoirs. In: Berger R, Suess HE, editors. Radiocarbon Dating. Proceedings of the Ninth International Conference. Los Angeles and La Jolla 1976. University of California Press. p 613-8.

Olsson IU. 1980a. ${ }^{14} \mathrm{C}$ in extractives from wood. Radiocarbon 22(2):515-24. 
Olsson IU. 1980b. Content of ${ }^{14} \mathrm{C}$ in marine mammals from northern Europe. Radiocarbon 22(3):662-75.

Olsson IU. 1983. Dating non-terrestrial materials. In: Hackens T, Mook WG, Waterbolk HT, editors. Proceedings of ${ }^{14} \mathrm{C}$ and Archaeology, Groningen, the Netherlands 1981. PACT 8:277-94.

Olsson IU. 1986a. ${ }^{13} \mathrm{C}$-variationer - deras orsak, storlek och användbarhet. Fornvännen 81:114-20. In Swedish, summary in English.

Olsson IU. 1986b. A study of errors in ${ }^{14} \mathrm{C}$ dates of peat and sediment. Radiocarbon 28(2A):429-35.

Olsson IU. 1988. Low-level counting using gas-filled counters as applied to ${ }^{14} \mathrm{C}$ dating with emphasis on reliability. In: Garcia-Leon M, Madurga G, editors. LowLevel Measurements and Their Applications to Environmental Radioactivity. Proceedings First International Summer School. La Rábida, Huelva, Spain, 28 September-9 October 1987. Singapore: World Scientific. p 171-223.

Olsson IU. 1989. Recent ${ }^{14} \mathrm{C}$ activity in the atmosphere, "clean air" and the Chernobyl effect. Radiocarbon 31(3):740-6.

Olsson IU. 1991a. Quality assessment of ${ }^{14} \mathrm{C}$ dates. Laborativ Arkeologi 5:115-23.

Olsson IU. 1991b. Accuracy and precision in sediment chronology. Hydrobiologia 214:25-34.

Olsson IU. 1993a. The importance of knowing the origin of samples in ${ }^{14} \mathrm{C}$ dating. In: Hackens $\mathrm{T}$, editorial group. Sources and Resources. PACT 38:211-22.

Olsson IU. 1993b. A ten-year record of the different levels of the ${ }^{14} \mathrm{C}$ activities over Sweden and the Arctic. Tellus B 45:479-81.

Olsson IU. 1997. Kol-14 datering. Metoden och diskussion av speciella problem med isländska prov och redovisning av två serier dateringar av arkeologiskt material. The Ása G. Wright Memorial Lectures IX. In Swedish. 63 p.

Olsson IU. 1999a. ${ }^{14} \mathrm{C}$ dates and the reservoir effect. In: van der Plicht J, editor. Proceedings International Workshop on Isotope-Geochemical Research in the Baltic Region, Lohusalu, Estonia, March 14-16 1996 Centre for Isotope Research, Groningen, the Netherlands. p 5-23.

Olsson IU. 1999b. Geophysical aspects of problems in interpretations of Icelandic radiocarbon dates of archaeological samples. Norwegian Archaeological Re view 32(2):95-110.

Olsson IU. 2000. Further tests of the EDTA treatment of bones. Radiocarbon 42(1):49-52.

Olsson I, Blake Jr W. 1961-2. Problems of radiocarbon dating of raised beaches, based on experience in Speitsbergen. Norsk Geografisk Tidsskrift 18(1-2): 47-64.

Olsson IU, Eriksson KG. 1965. Remarks on $\mathrm{C}^{14}$ dating of shell material in sea sediments. Progress in Oceanography 3:253-66.

Olsson IU, Florin M-B. 1980. Radiocarbon dating of dy and peat in the Getsjö area, Kolmården, Sweden, to determine the rational limit of Picea. Boreas 9(4): 289-305.

Olsson IU, Karlén I. 1963. The half-life of $\mathrm{C}^{14}$ and the problems which are encountered in absolute measurements on $\beta$-decaying gases. In: Radioactive Dating. Vienna: IAEA. p 3-11.

Olsson IU, Karlén I. 1965. Uppsala radiocarbon measurements VI. Radiocarbon 7:331-5.

Olsson IU, Kaup E. 2001. The varying radiocarbon activity of some recent submerged Estonian plants grown in the early 1990s. Radiocarbon 43(2B):809-20.

Olsson IU, Kilicci S. 1964. Uppsala natural radiocarbon measurements IV. Radiocarbon 6:291-307.

Olsson IU, Osadebe FAN. 1974. Carbon isotope variations and fractionation corrections in ${ }^{14} \mathrm{C}$ dating. Boreas 3:139-46.

Olsson IU, Possnert G. $1992 .{ }^{14} \mathrm{C}$ activity in different sections and chemical fractions of oak tree rings, $\mathrm{AD}$ 1938-1981. Radiocarbon 34(3):757-67.

Olsson IU, Stenberg A. 1967. Very high ${ }^{14} \mathrm{C}$ activity in Abisko, Sweden, during summer 1965. In: Radioactive Dating and Methods of Low-Level Counting. Vienna: IAEA. p 69-78.

Olsson IU, Vasari Y. 1995. The long-term response of submerged plants in the hard-water lake, Säynäjälampi, to the bomb-radiocarbon injection. In: Robertsson A-M, Hicks S, Åkerlund A, Risberg J, Hackens T, editors. Landscapes and Life. PACT 50:377-83.

Olsson I, Cazeneuve H, Gustavsson J, Karlén I. 1961. Uppsala natural radiocarbon measurements III. $R a$ diocarbon 3:81-5.

Olsson IU, Karlén I, Turnbull AH, Prosser NJD. 1962. A determination of the half-life of $\mathrm{C}^{14}$ with a proportional counter. Arkiv för Fysik 22:237-55.

Olsson IU, Göksu Y, Stenberg A. 1968. Further investigations of storing and treatment of foraminifera and mollusks for $\mathrm{C}^{14}$-dating Geologiska Föreningens $i$ Stockholm Förhandlingar 90:417-26.

Olsson IU, El-Gammal S, Göksu Y. 1969. Uppsala natural radiocarbon measurements IX. Radiocarbon 11(2): 515-44.

Olsson IU, Klasson M, Abd-El-Mageed A. 1972. Uppsala natural radiocarbon measurements XI. Radiocarbon 14(1):247-71.

Olsson IU, El-Daoushy MFAF, Abd-El-Mageed A, Klasson M. 1974. A comparison of different methods for pretreatment of bones. I. Geologiska Föreningens $i$ Stockholm Förhandlingar 96:171-81.

Olsson IU, El-Daoushy F, Vasari Y. 1983. Säynäjälampi and the difficulties inherent in the dating of sediments in a hard-water lake. Hydrobiologia 103:5-14.

Olsson IU, Holmgren B, Skye E. 1984. Questions arising when using lichen for ${ }^{14} \mathrm{C}$ measurements in climatic studies. In: Mörner N-A, Karlén W, editors. Climatic Changes on a Yearly to Millennial Basis. Dordrecht: D Reidel Publishing Company. p 303-8. 
Östlund HG. 1959. Stockholm natural radiocarbon measurements II. American Journal of Science Radiocarbon Supplement 1:35-44.

Östlund HG, Engstrand LG. 1960. Stockholm natural radiocarbon measurements III. American Journal of Science Radiocarbon Supplement 2:186-96.

Östlund HG, Engstrand LG. 1963. Stockholm natural radiocarbon measurements V. Radiocarbon 5:203-27.

Otlet RL. 1979. An assessment of laboratory errors in liquid scintillation methods of ${ }^{14} \mathrm{C}$ dating. In: Berger R, Suess HE, editors. Radiocarbon Dating. Proceedings of the Ninth International Conference. Los Angeles and La Jolla 1976. University of California Press. p 256-67.

Otlet RL, Slade BS. 1974. Harwell radiocarbon measurements I. Radiocarbon 16(2):178-91.

Otlet RL, Evans GV. 1983. Progress in the application of miniature gas counters to radiocarbon dating of small samples. In: Hackens T, Mook WG, Waterbolk HT, editors. Proceedings of ${ }^{14} \mathrm{C}$ and Archaeology, Groningen, the Netherlands 1981. PACT 8:213-22.

Otlet RL, Walker AJ, Longley H. 1983. The use of ${ }^{14} \mathrm{C}$ in natural materials to establish the average gaseous dispersion patterns of releases from nuclear installations. Radiocarbon 25(2):593-602.

Overbeck F, Münnich KO, Aletsee L, Averdieck FR. 1957. Das Alter des "Grenzhorizonts" norddeutscher Hochmoore nach Radiocarbon-Datierungen. Flora 45:37-71.

Pazdur MF, Zastawny A. 1987. Drastic increase of background in the Gliwice Radiocarbon Laboratory during late April, 1986, and its time changes. Radiocarbon 29(1):156-8.

Pearson GW. 1979. Precise ${ }^{14} \mathrm{C}$ measurements by liquid scintillation counting. Radiocarbon 21(1):1-21.

Pearson GW, Stuiver M. 1986. High-precision calibration of the radiocarbon time scale 500-2500 BC. Radiocarbon 28(2B):839-62.

Polach D. 1988. Radiocarbon Dating Literature. The first 21 years 1947-1968. London: Academic Press. $370 \mathrm{p}$.

Polach H. 1973. Cross checking of NBS oxalic acid and secondary laboratory radiocarbon standards. In: Proceedings of the Eighth International Radiocarbon Dating Conference. Lower Hutt, New Zealand, 18-25 October 1972. p 688-717.

Polach HA. 1979. Correlation of ${ }^{14} \mathrm{C}$ activity of NBS oxalic acid with Arizona 1850 wood and ANU Sucrose standards. In: Berger R, Suess HE, editors. Radiocarbon Dating. Proceedings of the Ninth International Conference. Los Angeles and La Jolla 1976. University of California Press. p 115-24.

Polach HA, Krueger HW. 1973. Isotopic fractionation of NBS oxalic acid and ANU-sucrose radiocarbon dating standards. In: Proceedings of the Eighth International Radiocarbon Dating Conference. Lower Hutt, New Zealand, 18-25 October 1972. p 719-26.
Polach HA, Krueger HW, Bannister B, Damon PE, Rafter AT. 1973. Correlation of $\mathrm{C}^{14}$ activity of NBS oxalic with Arizona-1850 wood and ANU-sucrose radiocarbon dating standards: a preliminary report of investigations and results. In: Proceedings of the Eighth International Radiocarbon Dating Conference. Lower Hutt, New Zealand, 18-25 October 1972. p 686-7.

Povinec P, Chudý M, Šivo 1986. Anthropogenic radiocarbon: past, present, and future. Radiocarbon 28(2A) 668-72.

Radnell CJ, Aitken MJ, Otlet RL. 1979. In situ ${ }^{14} \mathrm{C}$ production in wood. In: Berger R, Suess HE, editors. Radiocarbon Dating. Proceedings of the Ninth International Conference. Los Angeles and La Jolla 1976. University of California Press. p 643-57.

Ralph EK, Michael HN. 1970. MASCA radiocarbon dates for sequoia and bristlecone-pine samples. In: Olsson IU, editor. Radiocarbon Variations and Absolute Chronology. Nobel Symposium 12, Uppsala, 1115 August 1969. Stockholm: Almqvist \& Wiksell; New York: John Wiley \& Sons.p 619-23.

Ralph EK, Michael HN, Han MC. 1973. Radiocarbon dates and reality. MASCA Newsletters 9(1):1-20.

Revelle R, Suess HE. 1957. Carbon dioxide exchange between atmosphere and ocean and the question of an increase of atmospheric $\mathrm{CO}_{2}$ during the past decades. Tellus 9:18-27.

Sand-Jensen K, Prahl C. 1982. Oxygen exchange with the lacunae and across leaves and roots of the submerged vascular macrophyte, Lobelia dortmanna $\mathrm{L}$. The New Phytologist 91:103-20.

Saupé F, Strappa O, Coppens R, Guillet B, Jaegy R. 1980. A possible source of error in ${ }^{14} \mathrm{C}$ dates: volcanic emanations (examples from the Monte Amiata district, provinces of Grosetto and Sienna, Italy). Radiocarbon 22(2):525-31.

Säve-Söderbergh T, Olsson IU. 1970. C14 dating and Egyptian chronology. In: Olsson IU, editor. Radiocarbon Variations and Absolute Chronology. Nobel Symposium 12, Uppsala, 11-15 August 1969. Stockholm: Almqvist \& Wiksell; New York: John Wiley \& Sons. p 35-55.

Schove DJ. 1955. The sunspot cycle 649 B.C. to 2000 A.D. Journal of Geophysical Research 60(2):127-45.

Segl M, Levin I, Schoch-Fischer H, Münnich M, Kromer B, Tschiersch J, Münnich KO. 1983. Anthropogenic ${ }^{14} \mathrm{C}$ variations. Radiocarbon 25(2):583-92.

Šilar J. 1976. Radiocarbon ground-water dating in Czechoslovakia-first results. Věstnik Ústrědniho ústavu Geologického 51:209-20.

Smith FA, Walker NA. 1980. Photosynthesis by aquatic plants: effects of unstirred layers in relation to assimilation of $\mathrm{CO}_{2}$ and $\mathrm{HCO}_{3}{ }^{-}$and to carbon isotopic discrimination. The New Phytologist 86:245-59.

Søndergaard M, Sand-Jensen K. 1979. Carbon uptake by leaves and roots of Littorella uniflora (L.) Aschers. 
Aquatic Botany 6:1-12.

Sonninen E, Jungner H, Erämetsä P. 1985. Dating of mortar and bricks from the castle of Kastelholm. In: Edgren T, Jungner H, editors. Proceedings Third Nordic Conference on the Application of Scientific Methods in Archaeology, Mariehamn, Åland. Iskos 5:3849 .

Stafford Jr TW, Jull AJT, Brendel K, Duhamel RC, Donahue D. 1987. Study of bone radiocarbon dating accuracy at the University of Arizona NSF Accelerator Facility for Radioisotope Analysis. Radiocarbon 29(1):24-44.

Steemann Nielsen E. 1946. Carbon sources in the photosynthesis of aquatic plants. Nature 158(4017):594-6.

Stenhouse MJ, Baxter MS. 1976. Glasgow University radiocarbon measurements VIII. Radiocarbon 18(2): 161-171.

Stenhouse MJ, Baxter MS. 1977. Bomb ${ }^{14} \mathrm{C}$ as a biological tracer. Nature 267(5614):828-32.

Strömberg B. 1985. Revision of the lateglacial Swedish varve chronology. Boreas 14:101-5.

Stuiver M. 1961. Variations in radiocarbon concentration and sunspot activity. Journal of Geophysical Research 66(1):273-6.

Stuiver M. 1965. Carbon-14 content of 18th- and 19thcentury wood: variations correlated with sunspot activity. Science 149(3683):533-5.

Stuiver M. 1978a. Atmospheric carbon dioxide and carbon reservoir changes. Science 199(4326):253-8.

Stuiver M. 1978b. Radiocarbon timescale tested against magnetic and other dating methods. Nature 273(5660):271-4.

Stuiver M. 1980. Workshop on ${ }^{14} \mathrm{C}$ data reporting. Radiocarbon 22(3):964-6.

Stuiver M. 1982. A high-precision calibration of the AD radiocarbon time scale. Radiocarbon 24(1):1-26.

Stuiver M. 1983. International agreements and the use of a new oxalic acid standard. Radiocarbon 25(2):793-5.

Stuiver M, Becker B. 1986. High-precision decadal calibration of the radiocarbon time scale, AD 1950-2500 BC. Radiocarbon 28(2B):863-910.

Stuiver M, Becker B. 1993. High-precision decadal calibration of the radiocarbon time scale, AD 1950-6000 BC. Radiocarbon 35(1):35-65.

Stuiver M, Deevey ES. 1961. Yale natural radiocarbon measurements VI. Radiocarbon 3:126-40.

Stuiver M, Deevey ES. 1962. Yale natural radiocarbon measurements VII. Radiocarbon 4:250-62.

Stuiver M, Pearson GW. 1986. High-precision calibration of the radiocarbon time scale AD 1950-500 BC. Radiocarbon 28(2B):805-38.

Stuiver M, Polach HA. 1977. Discussion: reporting of ${ }^{14} \mathrm{C}$ data. Radiocarbon 19(3):355-63.

Stuiver M, Quay PD. 1980. Changes in atmospheric carbon-14 attributed to a variable sun. Science 207(4426):11-9.

Stuiver M, Reimer PJ. 1986. A computer program for ra- diocarbon age calibration. Radiocarbon 28(2B): 1022-30.

Stuiver M, Suess HE. 1966. On the relationship between radiocarbon dates and true ages. Radiocarbon 8:53440.

Stuiver M, Heusser CJ, Che Yang I. 1978. North American glacial history extended to 75,000 years ago. Science 200(4337):16-21.

Stuiver M, Kromer B, Becker B, Ferguson CW. 1986a. Radiocarbon age calibration back to 13,300 years BP and the ${ }^{14} \mathrm{C}$ age matching of the German oak and US Bristlecone pine chronologies. Radiocarbon 28(2B): 969-79.

Stuiver M, Pearson GW, Braziunas T. 1986b. Radiocarbon age calibration of marine samples back to 9000 cal yr BP. Radiocarbon 28(2B):980-1021.

Stuiver M, Reimer PJ, Braziunas TF. 1998. High-precision radiocarbon age calibration for terrestrial and marine samples. Radiocarbon 40(3):1127-51.

Suess HE. 1953. Natural radiocarbon and the rate of exchange of carbon dioxide between the atmosphere and the sea. In: Proceedings of the Williams Bay Conference on Nuclear Settings. p 52-6.

Suess HE. 1954. Natural radiocarbon measurements by acetylene counting. Science 120(3105):5-7.

Suess HE. 1955. Radiocarbon concentration in modern wood. Science 122(3166):415-7.

Suess HE. 1968. Climatic changes, solar activity, and the cosmic-ray production rate of natural radiocarbon. Meteorological Monographs 8(30):146-50.

Suess HE. 1970a. Bristlecone-pine calibration of the time-scale 5200 B.C. to the present. In: Olsson IU, editor. Radiocarbon Variations and Absolute Chronology. Nobel Symposium 12, Uppsala, 11-15 August 1969. Stockholm: Almqvist \& Wiksell; New York: John Wiley \& Sons. p 303-11.

Suess HE. 1970b. The three causes of the secular C14 fluctuations, their amplitudes and time constants. In: Olsson IU, editor. Radiocarbon Variations and Absolute Chronology. Nobel Symposium 12, Uppsala, 1115 August 1969. Stockholm: Almqvist \& Wiksell; New York: John Wiley \& Sons. p 595-605.

Suess HE. 1979a. The ${ }^{14} \mathrm{C}$ level during the fourth and second half of the fifth millennium B.C and the ${ }^{14} \mathrm{C}$ calibration curve. In: Berger R, Suess HE, editors. Radiocarbon Dating. Proceedings of the Ninth International Conference. Los Angeles and La Jolla 1976. University of California Press. p 538-44.

Suess HE. 1979b. A calibration table for conventional radiocarbon dates. In: Berger R, Suess HE, editors. Radiocarbon Dating. Proceedings of the Ninth International Conference. Los Angeles and La Jolla 1976. University of California Press. p 777-84.

Suess HE. 1980. The radiocarbon record in tree rings of the last 8000 years. Radiocarbon 22(2):200-9.

Suess HE. 1986. Secular variations of cosmogenic ${ }^{14} \mathrm{C}$ on Earth: their discovery and interpretation. Radiocarbon 
28(2A):259-65.

Sulerzhitzky LD. 1970. Radiocarbon dating of volcanoes. Bulletin Volcanologique 35:85-94.

Switsur VR. 1973. Combustion bombs for radiocarbon dating. In: Proceedings of the Eighth International Radiocarbon Dating Conference. Lower Hutt, New Zealand, 18-25 October 1972. p 120-32.

Tamers MA. 1966. Routine carbon-14 dating using liquid scintillation techniques. In: Chatters RM, editor. Proceedings of the Sixth International Conference Radiocarbon and Tritium Dating. Pullman, Washington, $7-$ 11 June 1965 (Conf. 650652). p 53-67.

Tans PP, Mook WG. 1979. Design, construction and calibration of a high accuracy carbon-14 counting set up. Radiocarbon 21(1):22-40.

Tans PP, Mook WG. 1980. Past atmospheric $\mathrm{CO}_{2}$ levels and the ${ }^{13} \mathrm{C} /{ }^{12} \mathrm{C}$ ratios in tree rings. Tellus 32:268-83.

Tauber H. 1979. ${ }^{14} \mathrm{C}$ activity of Arctic marine mammals. In: Berger R, Suess HE, editors. Radiocarbon Dating. Proceedings of the Ninth International Conference. Los Angeles and La Jolla 1976. University of California Press. p 447-52.

Tauber H. 1981. ${ }^{13} \mathrm{C}$ evidence for dietary habits of prehistoric man in Denmark. Nature 292(5821):332-3.

Tauber H. 1983a. ${ }^{14} \mathrm{C}$ dating of human beings in relation to dietary habits. In: Hackens T, Mook WG, Waterbolk HT, editors. Proceedings of ${ }^{14} \mathrm{C}$ and Archaeology, Groningen, the Netherlands 1981. PACT 8:365-75.

Tauber H. 1983b. Possible depletion in ${ }^{14} \mathrm{C}$ in trees growing in calcareous soils. Radiocarbon 25(2):417-20.

Taylor RE. 1987. Radiocarbon Dating. San Diego: Academic Press. 212 p.

Thorarinsson S. 1944. Tefrokronologiska studier på Island. Geografiska Annaler Stockholm 26:1-217.

Troughton JH. 1973. Carbon isotope fractionation by plants. In: Proceedings of the Eighth International Radiocarbon Dating Conference. Lower Hutt, New Zealand, 18-25 October 1972. p 420-38.

Valastro Jr S, Land LS, Varela AG. 1977. An improved procedure for wet combustion of the ${ }^{14} \mathrm{C}$ NBS oxalic acid standard. Radiocarbon 19(3):375-82.

Valastro Jr S, Land LS, Varela AG. 1979. An improved procedure for wet oxidation of the ${ }^{14} \mathrm{C}$ NBS oxalic acid standard. In: Berger R, Suess HE, editors. Radiocarbon Dating. Proceedings of the Ninth International Conference. Los Angeles and La Jolla 1976. University of California Press. p 125-34. van der Merwe NJ, Vogel JC. $1978 .{ }^{13} \mathrm{C}$ content of human collagen as a measure of prehistoric diet in woodland North America. Nature 276(5690):815-6.

van Strydonck M, Dupas M, Dauchot-Dehon M. 1983. Radiocarbon dating of old mortars. In: Hackens T, Mook WG, Waterbolk HT, editors. Proceedings of ${ }^{14} \mathrm{C}$ and Archaeology, Groningen, the Netherlands 1981. PACT 8:337-43.

Vita-Finzi C, Roberts N. 1984. Selective leaching of shells for ${ }^{14} \mathrm{C}$ dating. Radiocarbon $26(1): 54-8$.

Vogel JC. 1960. Isotope separation factors of carbon in the equilibrium system $\mathrm{CO}_{2}-\mathrm{HCO}_{3}{ }^{-}-\mathrm{CO}_{3}{ }^{-}$. In: Summer Course on Nuclear Geology Varenna. p 21621.

Vogel JC, Fuls A, Visser E, Becker B. 1986. Radiocarbon fluctuations during the third millennium BC. Radiocarbon 28(2B):935-8.

Vogel JC, Fuls A, Visser E, Becker B. 1993. Pretoria calibration curve for short-lived samples 1930-3350 BC. Radiocarbon 35(1):73-85.

Walton A, Baxter MS, Callow WJ, Baker MJ. 1967. Carbon-14 concentrations in environmental materials and their temporal fluctuations. In: Radioactive Dating and Methods of Low-Level Counting. Vienna: IAEA. $\mathrm{p}$ 41-7.

Watt DE, Ramsden D, Wilson HW. 1961. The half-life of carbon-14. International Journal of Applied Radiation and Isotopes 11(1):68-74.

Wickman FE. 1952. Variations in the relative abundance of the carbon isotopes in plants. Geochimica et Cosmochimica Acta 2:243-54.

Willis EH, Tauber H, Münnich KO. 1960. Variations in the atmospheric radiocarbon concentration over the past 1300 years. American Journal of Science Radiocarbon Supplement 2:1-4.

Willkomm H, Erlenkeuser H. 1973. $\mathrm{C}^{14}$ measurements on water, plants and sediments of lakes. In: Proceedings of the Eighth International Radiocarbon Dating Conference. Lower Hutt, New Zealand, 18-25 October 1972. p 312-23.

Wilson AT, Gumbley JM, Speddin DJ. 1963. Resin metabolism in the sapwood of Pinus radiata. Nature 198(4879):500.

Wium-Andersen S. 1971. Photosynthetic uptake of free $\mathrm{CO}_{2}$ by the roots of Lobelia dortmanna. Physiologia Plantarum 25:245-8. 